\title{
An Assessment of the Bioavailability of Metals in Soils on Oil Palm Plantations in Nigeria
}

\author{
Bola O. Olafisoye ${ }^{1}$, Oluwafemi O. Oguntibeju ${ }^{2}$, Otolorin A. Osibote ${ }^{3 *}$ \\ ${ }^{1}$ Faculty of Applied Sciences, Department of Chemistry, Cape Peninsula University of Technology, \\ P.O.Box 652,Cape Town, South Africa 8000 \\ ${ }^{2}$ Faculty of Health and Wellness Sciences, Department of Biomedical Sciences, \\ Cape Peninsula University of Technology, P.O.Box 1906, Bellville, South Africa 7535 \\ ${ }^{3}$ Faculty of Applied Sciences, Department of Mathematics and Physics, \\ Cape Peninsula University of Technology, \\ P.O. Box 652, Cape Town, South Africa 8000
}

Received: 3 November 2014

Accepted: 2 December 2015

\begin{abstract}
We investigated the speciation, bioavailability, and mobility of metals in soils from selected states on oil palm plantations in southwest Nigeria. Soils were analysed for total metal content and speciation on all sampling locations. Metal concentrations were compared against $\mathrm{pH}$, electrical conductivity (EC) and soil organic matter (SOM), which were high at all the sampling locations. The speciation results deduced that the concentrations of the different fractions vary widely at each sampling location. $\mathrm{Cd}$ is mostly abundant in the exchangeable phase in all the samples analysed in the various locations. Ni in the Iresa-apa plantation (29.9\%) and Co in the Acharu plantation (29.9\%) also showed appreciable concentrations in the Fe/Mn oxide fractions. The concentrations of $\mathrm{Pb}$ and $\mathrm{Cu}$ were highest in the organic fraction. Metals in the organic phase are more released into soil solution when compared to the residual phase fractions. Chromium and Zinc were mostly associated with the residual phase when the values of the residual phase were compared with other geochemical fractions. The plantations under study, which recorded the highest concentrations of $\mathrm{Cr}$ and $\mathrm{Zn}$ in the residual fractions, were $87.9 \%$ (Okitipupa), 86.3\% (Ikire), 82.7\% (Apoje), 90.3\% (Onishere), $89.7 \%$ (Benin City), and $85.6 \%$ (Nsukka).The results of the sequential extraction show that mostly $\mathrm{Cr}$ and $\mathrm{Zn}$ were strongly bound to the residual/inert phase in all the soils under investigation. The potential mobility of the metals with high fractions in the residual phase is as follows: $\mathrm{Cr}(74.8 \%), \mathrm{Zn}(74.0 \%), \mathrm{Pb}(73 \%)$, $\mathrm{Fe}(69.5 \%), \mathrm{Ni}(67.0 \%), \mathrm{Cu}(63.8 \%), \mathrm{Mn}(30.5 \%), \mathrm{Co}(30.7 \%)$, and $\mathrm{Cd}(25.9 \%)$. These values were high when compared to the values of other metals in the other mobile and potentially mobile fractions.
\end{abstract}

Keywords: oil palm plantation, bioavaliability and bioaccessibility, heavy and trace metals, sequential extraction

*e-mail: osibotea@cput.ac.za 


\section{Introduction}

Palm oil (Elaeisguineensis) is edible oil that requires freshness prior to storage. It must be free from contaminants - especially metals. Metals have been investigated for accelerating the deterioration of fresh oils, causing rancidity. The oil palm tree is a tropical tree grown mainly for the industrial production of vegetable oil. For optimal growth and production, the crop requires high and year-round rainfall with minimal dry season and high temperatures. The soils in which the palm oil trees thrive are deep and well drained clay and humus of small particle size.

The socio-economic impacts of oil palm plantations are numerous in a good number of countries. Nigeria is known for the production of red palm oil, and is one of the largest exporters, with a yearly average export of more than 10,000 tons [1]. The oil palm is cultivated on large hectares of land, which are usually collected from small-scale farmers and controlled by state or local government areas. Problems that often arise include conflict of land ownership, and ecology and forest and wildlife conservation. There is also a controversy of food versus wildlife as loss of wildlife and plant species - as for example the orangutan in the case of Asian plantations - is lost when large forrests are cut down for propagation of oil palm plantations [2].

Oil from the palm fruit has considerable concentrations of vitamins A, C, and E. Palm oil has been shown by researchers to have the potential to cure some forms of cancer and heart disease [3]. The palm is an economic tree in Nigeria and no part of the tree is wasted. The oils extracted from the fresh fruit bunch and the kernel are used for culinary purposes. The oils are also useful as feedstock in agro allied and chemical industry. The leaves of the tree are used for the production of brooms, thatching for roofs, and the making of baskets in some parts of Africa. The palm kernel shells are converted into fuel, compost manure, and fertilizers, and can be used for mulching and in some pre-planting operations and for industrial purposes. The trunk of the oil palm contains sap, which is used for wine and the production of yeast in some parts of the world. Being an economic crop, less energy is expended in its cultivation and processing compared to yield. Palm oil plantations provide benefits for farmers and their families and employment for the rural populace [4].

The ostensible environmental effects of the cultivation and management of palm oil trees cuts across land and water contamination. Many physical, biological, industrial, and agricultural processes bring about the pollution of soils, since soils represent a vibrant and vigorous structure. The contamination of soils may arise from the buildup of metals, since metals have the ability to accumulate and bioaccumulate in soils. According to Orisakwe et al., the accumulation of metals in soils is an ecotoxicology issue that adversely affects the environment. Metal contamination in the environment is irreversible; it persists and is usually non-biodegradable. Metal contamination leads to long residence time in the environment, which ends up in the food chain. Natural factors such as geology of metal contamination of the environment is minimal. Mostly, contamination arises from anthropogenic sources such as unwholesome farming practices, which include bush burning and the use of fertilizers and pesticides containing metals. Mining, smelting of metals and ferrous ions, galvanizing, electroplating, automobile and energy emissions, fuel production, pesticide use, and the use of slush and fertilizers on farmlands have polluted soils extensively [5].

The study area comprises several oil palm plantations situated close to petroleum- and non-petroleum-based industries, plus mining and agricultural industries. These pollutants alongside domestic effluents are deposited into the plantations from runoff. The indiscriminate discharge of petroleum- and non-petroleum-based products into water and apparently the percolating of metals into soil have polluted such soils. Metals such as $\mathrm{Cd}, \mathrm{Pb}, \mathrm{Hg}$, and As are considered environmental pollutants because they have no known benefits to life [6]. Others, such as $\mathrm{Cu}, \mathrm{Cr}$, $\mathrm{Ni}$, and $\mathrm{Zn}-$ although toxic at elevated concentrations are essential to plants and animals.

The $\mathrm{pH}$ of Nigerian soil, which is acidic, is a major contribution to the toxicity of metals in soils. Plants like the oil palm tree are important components of the ecosystem as they aid in the transportation of metals from abiotic into biotic environments [7]. The bioavailability of metals to plants is controlled by factors such as climate, sorption, and desorption processes, speciation, redox reactions, soil type, and the response of plants to nutrients. Only metals in aqueous soil solutions are available to plants. Whether soil metals will form complexes with organic or inorganic matter, mineral colloids, or exist as free ions in soil solution depend on factors such as $\mathrm{pH}$, root respiration organic matter, and redox reactions. Soil acidity is a useful indicator of the availability of metals to plants. This property is described as the soil $\mathrm{pH}$, but actually it is the $\mathrm{pH}$ of the solution of the soil [8]. When measured, this describes a useful property and gives information about the soil. At low $\mathrm{pH}$ metals such As, $\mathrm{Zn}$, and Mn compete with $\mathrm{H}^{+}$and $\mathrm{Al}^{3+}$ in the cation exchange complex, and $\mathrm{Fe}^{3+}$ and $\mathrm{Al}^{3+}$ are released into the soil solution. These ions are toxic to plants and animals but at higher $\mathrm{pH}$ these metals are readily soluble and freely available in the soil solution [9]. A high organic matter and clay content suggest that metals can be retained in these soils as these properties increase the adsorption capacities of these metals in soil. For metals to be translocated by water through the soil profile, they have either to be in the soluble phase or bound to mobile particles. Metals can also form complexes with particles of organic matter in topsoil and profile depth [10].

Speciation has been defined by a few researchers as the identification and the speciation of different species, forms, or phases in which an element occurs. Metals are bound in soils in various oxidation states [11-16]. The toxicity of such metals differs with oxidation states. A major concern of regulatory agencies worldwide is the susceptibility of metals in the environment. Biological, geological, and anthropogenic factors affect the bio-availability 
and bio-accessibility of the concentrations of metals in soils [12]. Bio-availability of metals in soils differs extensively from bioaccessibility. The speciation of the metals, its biotransformation, the weathering of the parent material and its adsorption, electrical conductivity, cation exchange capacity (CEC), and $\mathrm{pH}$ are factors responsible for its bioaccessibility and bioavailability. Total metal concentration is not sufficient to qualify and quantify metal speciation or the behavior of metals in soils because such metals are present in soils in various oxidation states that influence their availability and uptake by plants. Total metal concentration is of interest for geochemical implication, but speciation is more important for agriculture. This is described in terms of what is available for plant uptake from soil solution [13-15]. If bioavailability is proportional to mobility, then mobile toxic metals will be readily available for plant uptake of soil solution through the root hairs. Metals are usually present in different forms or fractions, such as exchangeable fractions, carbonate-bound fractions, iron- and manganese oxide-bound fractions, organic bound fractions, and residual fractions. Metals can form complexes with particles of organic matter in topsoil, and as such can be located vertically along the profile depth. Water-soluble and exchangeable fractions and sometimes organic fractions and iron- and manganese-bound fractions are the bioavailable forms. A consequence of organic matter concentration is the metal binding to dissolved organic carbon (DOC). An increase of DOC concentration increases the metal complexation with organic matter. Consequently, the proportion of the concentrations of metals in the liquid phase increases the mobility of the metals [16].

Therefore, knowledge of the total concentrations of metals alone is not adequate to evaluate the environmental effect of these metals in soils. In order to qualify and quantify the fractions or forms in which a metal exists in soils, it is crucial to obtain detailed knowledge and perception of the probable and genuine effects of the concentrations of these metals in the soils. Other factors to consider include high concentrations of the metals under study, translocation and transportation, and altering climatic situations. The extraction scheme developed by Tessier et al. 1979, established an extraction procedure that permits the classification of the total metal concentration into five segments: exchangeable fractions, carbonate-bound fractions, iron/manganese oxide-bound fractions, organic bound fractions, and residual fractions. Initially this scheme was applied for sediments, but it has now been used extensively in soil speciation [1113].

Much research has been conducted on the speciation of metals in soils in some parts of the world [10-23]. Heavy metal speciation and its bioavailability and bioaccessibility in Nigerian soils have been studied [15, 24-26]. A biomonitoring update on a review written by Orisakwe et al. (2014) reveals that Nigerian soils are polluted. He performed a comprenhensive review of Nigerian soils revealing that a million people die each year across Africa due to environmental risk factors, of which metal pollution is the highest [27]. Due to this reason, a study on the total content of metals, speciation of metals, and the bioavailability and mobility of these metals in soils from selected states on oil palm plantations in southwestern Nigeria was investigated.

\section{Experimental Procedure}

\section{Sampling}

Soil sampling was accomplished on 15 main sites in land areas in the southern states in Nigeria. These sites are the nine sub-stations of the Nigerian Institute for Oil Palm Research (NIFOR) in Abak, Akwa Ibom State, Acharu, Kogi State, Agbarho, Delta State, Onishere, Ondo State, Ubiaja, Edo State, Umuabi, Enugu State, Nsukka, Enugu State, Ago-Emokpae, and Edo State, and from their headquarters at Benin. Five samples were also collected from other locations in Nigeria's southern States from oil palm plantations suffering from substantial pollution from metals. These locations were Ogbomoso, Oyo State, Igede-Ekiti, Ekiti State, Ikire, Osun State, Okitipupa oil palm plantation in Ondo State, and Apoje oil palm farm settlement in Ogun State. A composite sample was used for analysis, which was achieved by partitioning the sampling locations into four parts in each state, and soil samples were collected from each part in each state. The sampling locations were centered on reasons such as population density, farming communities, and regions receiving major contamination. An auger was used for soil sample collection and the samples were stored in sterilized tight plastic bags. This was preserved instantly in an ice chest at $4^{\circ} \mathrm{C}$. Soils were air-dried, sieved using a $2 \mathrm{~mm}$ aperture sieve, preserved in plastic bags, and further dried at $105 \pm 5^{\circ} \mathrm{C}$ for three hours. The apparatus used were properly washed in nitric acid and rinsed in distilled water [28]. Generally, soils are made of a lot of materials that comprise mostly of silt, with a high degree of clay. Tropical soils - especially on oil palm plantations - are deep and well drained. Soils also contain some degree of organic matter arising from the decomposition of dead plant and animal matter.

\section{Reagents and Standards}

The solutions used for analysis were prepared from analytical-grade reagents using high purity deionized water (Milli-Q water purification system, Millipore, Belford, MA, USA). Analytical grade chemicals from Merck, Darmstadt, Germany and Sigma-Aldrich were used for all analyses. Reference materials for standard calibration curves were prepared from single element standards $(1000 \mathrm{mg} / \mathrm{L})$. The starting materials for the standards were measured against a certified reference material and are traceable to NIST. Lower concentrations were prepared in the same matrix using the non-serial dilution method [28]. 


\section{Electrical Conductivity and $\mathrm{pH}$ Determination}

Aqueous extracts of samples were obtained by dissolving $20 \mathrm{~g}$ of soil sample with $100 \mathrm{~cm}^{3}$ of ultra-pure water (Millipore distilled water $18.2 \mu \mathrm{m}$ ) in a beaker for the determination of electrical conductivity and $\mathrm{pH}$. A digital $\mathrm{pH}$ meter was used for this purpose. The soil mixture was stirred for 30 minutes at $40^{\circ} \mathrm{C}$ and allowed to cool for about an hour. The suspended soil mixture was used to determine $\mathrm{pH}$ and conductivity [29-30].

\section{Organic Matter Determination: Loss on Ignition Method}

The routine estimation of soil organic matter by the loss of weight was achieved using the loss on ignition (LOI) method. This involves heating the sample to as high as $600^{\circ} \mathrm{C}$ to decompose most or all organic matter and carbonates. The previously dried and sieved samples were oven-dried at $105^{\circ} \mathrm{C}$, cooled in a desiccator, and weighed. The weighed samples were further combusted in a muffle furnace (Memmert oven, Model 380 ) at $600^{\circ} \mathrm{C}$ for 4 hours, cooled in a desiccator, and reweighed [29-30].

\section{Total Metal Extraction Using Microwave-Assisted Digestion Method}

Digestion was performed using the Milestone Ethos Microwave Lab Station. Total metal extraction using microwave assisted digestion was performed as follows: $1 \mathrm{~g}$ of finely ground and homogenized soil was digested using the aqua regia digestion method $\left(\mathrm{HNO}_{3} / \mathrm{HCl}\right.$ in $1: 3$ ratios). Millipore distilled water $(18.2 \mu \mathrm{m})$ was added to the digested soil volume and the volume increased to $100 \mathrm{~mL}$. The contents in the Teflon tubes after microwaveassisted digestion were transferred to centrifuge tubes $(50 \mathrm{~mL})$. These were centrifuged at $3,000 \mathrm{rpm}$ for $30 \mathrm{mins}$ and filtered through a filter paper $(0.45 \mu \mathrm{m})$. The extract volume $(10 \mathrm{~mL})$ was put in polypropylene tubes $(15 \mathrm{~mL})$ and stored at $4^{\circ} \mathrm{C}$ for ICP-OES instrumental analysis.

\section{Sequential Extraction Procedure}

The sequential extraction procedure consists of the following fractions [15, 24-27]:

- Exchangeable;

- Bound to carbonates and sulphides;

- Bound to manganese and iron oxides;

- Bound to organic matter;

- Residual/Inert fraction.

\section{Exchangeable Fraction}

The samples $(1 \mathrm{~g})$ of soil were weighed and extracted with $16 \mathrm{~mL}$ magnesium chloride at $\mathrm{pH} 7$ under room temperature. The soils were shaken and centrifuged at $3,000 \mathrm{rpm}$ for 30 minutes. The top liquid layer was poured into a $15 \mathrm{~mL}$ polypropylene tube and stored at $4^{\circ} \mathrm{C}$ prior to elemental analysis in the fraction. The residue from the first step was washed with $10 \mathrm{~mL}$ ultra-pure distilled water (Millipore water $18.2 \mu \mathrm{m}$ ). The residual soil was used for the subsequent extraction. This process involves an adsorption-desorption process where weak adsorbed metals in soils are released through ion exchange processes.

\section{Fraction Bound to Carbonates and Sulphides}

The second step of the analysis consists of the acidsoluble fraction, which is bound to carbonates and sulphides. Metals extracted in this fraction are affected by ion exchange and $\mathrm{pH}$ since carbonates can be precipitated with metals at appropriate $\mathrm{pH}$. To the residue of the first step, $0.11 \mathrm{~mol} / \mathrm{L}$ of acetic acid $(20 \mathrm{~mL})$ was added to the polypropylene tubes. The polypropylene tubes were shaken for 16 hours at room temperature prior to centrifuging. Centrifugation was performed at 3,000 rpm for 30 minutes. The top liquid layer was poured into a $15 \mathrm{~mL}$ polypropylene tube and stored at $4^{\circ} \mathrm{C}$ prior to elemental analysis in the fraction. The residue was washed with $10 \mathrm{~mL}$ ultra-pure distilled water (Millipore water $18.2 \mu \mathrm{m}$ ). The residue was shaken for 10 minutes and centrifuged at $3,000 \mathrm{rpm}$. This was done to remove all traces of the acetic acid.

\section{Bound to Manganese and Iron Oxides}

Magnesium and iron oxides have large surface areas for absorbing metals. Under the reducing conditions of the analysis, iron (III) and manganese (IV) ions could be released and adsorbed by the metal. The third fraction of the analysis consists of the reducible fraction, which is bound to iron and manganese oxides. The metals bound to iron and manganese oxides were separated from the residue of the second step by using $0.5 \mathrm{~mol} / \mathrm{L}$ hydroxylaminehydrochloride $(20 \mathrm{~mL})$ and adjusted to pH 2 with nitric acid.The contents in the polypropylene tubes were shaken for 16 hours, and further centrifuged for about 10 minutes. The supernatant from the third fraction was poured into a $15 \mathrm{~mL}$ polypropylene tube and stored at $4{ }^{\circ} \mathrm{C}$ prior to metal analysis. The soil residue from this step was washed with $20 \mathrm{~mL}$ ultra-pure distilled water (Millipore water $18.2 \mu \mathrm{m}$ ) centrifuged, and the supernatant discarded and the residue was used for the next analysis.

\section{Bound to Organic Matter}

The oxidizable fraction is the fraction that is bound to organic matter in the soil samples. Metals may undergo complexation and bioaccumulation of organic matter from decayed and dead organisms. Degradation through oxidation has the potential to release the bound metals, making it bioassessible to plants. Approximately $10 \mathrm{~mL}$ of $8.8 \mathrm{~mol} / \mathrm{L}$ hydrogen peroxide adjusted to $\mathrm{pH} 2$ with nitric acid was added drop-wise to the residue from the third fraction and digested in a water bath at $30^{\circ} \mathrm{C}$ for one hour. The $50 \mathrm{~mL}$ centrifuge tube was lightly capped and digestion was continued at $85^{\circ} \mathrm{C}$ for 30 minutes 
until the volume of liquid in the centrifuge was reduced to $2 \mathrm{~mL}$. The procedure was continued with $5 \mathrm{~mL}$ of $8.8 \mathrm{~mol} /$ LHydrogen peroxide until the volume was reduced to near dryness. The contents were cooled and $25 \mathrm{mLof} 1.0 \mathrm{~mol} / \mathrm{L}$ ammonium acetate was added.This was shaken and centrifuged at 3,000 rpm for 16 hours. It was decanted and the extract stored at $4{ }^{\circ} \mathrm{C}$ for metal analysis. The residual soil from the extraction was washed and used for the next extraction.

\section{Residual/Inert Fraction}

This fraction is the inert or residual fraction. In this fraction, metals are bound to the crystalline lattice, which consists of mineral compounds. The analysis of the residue was done using the aqua regia method. The extract from the fourth fraction was digested using the microwave assisted digestion method. This was done for metals that were not soluble in the preceding step.

The results of the sequential extraction procedure were validated by comparing the sum of the various geochemical fractions for each element in the various sampling locations with the result obtained from the microwave-assisted acid digestion. The microwaveassisted acid digestion was used to as an extraction method to determine the total metal contents in the samples.

\section{Validation and Quality Assurance of the Analytical Method}

The repeatability or precision of the method was established with an evaluation of the percentage residual standard deviation of the sample microwave-assisted digestion procedure. Digested samples were analyzed in triplicate. The mean standard deviation and percentage residual standard deviation were calculated from this data. The acceptable criterion for repeatability and percentage residual standard deviation results should be below 10 for elements determined by ICP-OES. The accuracy of the sequential extraction procedure was validated by comparing the results obtained from the analysis with a certified reference material (CRM 218-225G), Sigma Aldrich-certified material. The results were compared and the recovery rates were satisfactory at between $85 \%$ and $90 \%$.

Internal recovery checks on the results of the microwave extraction procedure on the sequential extraction procedure were performed. This was achieved by comparing the total of the four fractions (exchangeable + carbonates and sulphides + manganese and iron oxides + organic matter and sulphides + residual /inert fraction) with the results of total metal extraction that was performed on the results obtained from the microwave extraction procedure. The formula used is:

Fraction $1+$ Fraction $2+$ Fraction $3+$ Fraction $4+$ Fraction 5 Total digestion
Table 1. Chemical properties of soils (mean+standard deviation) at different sampling locations.

\begin{tabular}{|c|c|c|c|c|}
\hline Code & Location & $\mathrm{pH}$ & $\begin{array}{c}\mathrm{EC} \\
(\mu \mathrm{s} / \mathrm{cm})\end{array}$ & $\begin{array}{c}\mathrm{SOM} \\
\left(\mathrm{gkg}^{-1}\right)\end{array}$ \\
\hline S1 & Abak & $5.12 \pm 0.03$ & $105 \pm 0.01$ & $3.26 \pm 0.01$ \\
\hline S2 & Acharu & $5.58 \pm 0.02$ & $134 \pm 0.01$ & $7.86 \pm 0.02$ \\
\hline S3 & Agbarho & $5.15 \pm 0.02$ & $23 \pm 0.02$ & $3.39 \pm 0.02$ \\
\hline S4 & Ago-Emokpae & $5.41 \pm 0.01$ & $190 \pm 0.01$ & $9.73 \pm 0.02$ \\
\hline S5 & Apoje & $5.51 \pm 0.05$ & $104 \pm 0.03$ & $3.54 \pm 0.01$ \\
\hline S6 & Badagry & $5.01 \pm 0.03$ & $229 \pm 0.02$ & $4.06 \pm 0.02$ \\
\hline S7 & Benin City & $5.06 \pm 0.01$ & $30 \pm 0.02$ & $3.45 \pm 0.01$ \\
\hline S8 & Igede-Ekiti & $7.01 \pm 0.01$ & $137 \pm 0.01$ & $3.82 \pm 0.03$ \\
\hline S9 & Ikire & $5.47 \pm 0.02$ & $122 \pm 0.01$ & $4.08 \pm 0.01$ \\
\hline S10 & Iresa-apa & $5.37 \pm 0.01$ & $225 \pm 0.01$ & $5.03 \pm 0.01$ \\
\hline S11 & Nsukka & $5.16 \pm 0.03$ & $171 \pm 0.02$ & $3.45 \pm 0.01$ \\
\hline S12 & Onishere & $5.02 \pm 0.02$ & $22 \pm 0.02$ & $3.79 \pm 0.03$ \\
\hline S13 & Okitipupa & $5.18 \pm 0.01$ & $111 \pm 0.01$ & $3.24 \pm 0.02$ \\
\hline S14 & Ubiaja & $4.96 \pm 0.01$ & $216 \pm 0.01$ & $4.47 \pm 0.01$ \\
\hline S15 & Umuabi & $5.41 \pm 0.03$ & $19 \pm 0.01$ & $2.76 \pm 0.01$ \\
\hline
\end{tabular}

$\mathrm{n}=3 ; \mathrm{EC}=$ Electrical Conductivity;

$\mathrm{SOM}=$ Soil Organic Matter.

\section{Results}

Table 1 presents the results of the chemical characteristics of the soils. This shows the mean and standard deviation values for $\mathrm{pH}$, electrical conductivity (EC), and soil organic matter (SOM) of soils at various sampling points. Mean and standard deviation values $\left(\mathrm{mgkg}^{-1}\right)$ for total metal extraction using the microwaveassisted digestion method in soils is presented in Table 2. Table 3 shows values for the mobility of metal speciation. Table 4 presents the mean and standard deviations $\left(\mathrm{mgkg}^{-1}\right)$ of the sequential extraction procedure on all soil samples.

\section{Discussion of Results}

\section{Chemical Properties of the Soils}

Table 1 shows the mean and standard deviation values of the chemical characteristics of soils at the various locations on the oil palm plantations in southwest Nigeria. The $\mathrm{pH}$ values of the soils were less than 6 and were generally acidic on all the soils of the locations sampled. The soil organic matter values were also relatively high at all the locations under study. The results on the soil properies were in agreement with the results obtained by Murungi et al. (2013) [31], who invesigated soils around open-air automobile mechanic workshops in the Ngara area of Nairobi, Kenya. It was also in agreement with the 
Table 2. Mean concentrations and standard deviation values $\left(\mathrm{mgkg}^{-1}\right)(\mathrm{n}=2)$ for total metal extraction using the microwave-assisted digestion method in soils.

\begin{tabular}{|c|c|c|c|c|c|c|c|c|c|}
\hline Code & $\mathrm{Cd}$ & $\mathrm{Co}$ & $\mathrm{Cr}$ & $\mathrm{Cu}$ & $\mathrm{Fe}$ & $\mathrm{Mn}$ & $\mathrm{Pb}$ & $\mathrm{Ni}$ & $\mathrm{Zn}$ \\
\hline $\mathrm{S} 1$ & $1.09 \pm 0.2$ & $9.42 \pm 0.3$ & $109.56 \pm 0.1$ & $39.11 \pm 0.2$ & $30.99 \pm 0.3$ & $0.88 \pm 0.1$ & $6.84 \pm 0.2$ & $40.66 \pm 0.1$ & $63.11 \pm 0.1$ \\
\hline $\mathrm{S} 2$ & $1.16 \pm 0.1$ & $2.17 \pm 0.1$ & $45.67 \pm 0.1$ & $12.92 \pm 0.1$ & $40.34 \pm 0.1$ & $19.22 \pm 0.1$ & $7.03 \pm 0.1$ & $37.24 \pm 0.2$ & $89.33 \pm 0.2$ \\
\hline $\mathrm{S} 3$ & $1.66 \pm 0.1$ & $3.98 \pm 0.2$ & $132.21 \pm 0.1$ & $45.06 \pm 0.4$ & $12.34 \pm 0.1$ & $0.23 \pm 0.2$ & $11.01 \pm 0.1$ & $39.11 \pm 0.1$ & $23.01 \pm 0.1$ \\
\hline $\mathrm{S} 4$ & $0.64 \pm 0.2$ & $2.07 \pm 0.1$ & $25.50 \pm 0.3$ & $35.08 \pm 0.1$ & $9.11 \pm 0.2$ & $9.42 \pm 0.3$ & $10.92 \pm 0.2$ & $30.27 \pm 0.1$ & $92.48 \pm 0.1$ \\
\hline S5 & $1.28 \pm 0.1$ & $1.03 \pm 0.1$ & $99.92 \pm 0.1$ & $33.22 \pm 0.1$ & $6.6 \pm 0.1$ & $0.45 \pm 0.1$ & $12.32 \pm 0.1$ & $35.67 \pm 0.1$ & $96.67 \pm 0.1$ \\
\hline S6 & $4.26 \pm 0.2$ & $2.61 \pm 0.1$ & $108.67 \pm 0.1$ & $69.11 \pm 0.1$ & $1.81 \pm 0.2$ & $1.33 \pm 0.2$ & $12.43 \pm 0.2$ & $49.08 \pm 0.1$ & $53.82 \pm 0.2$ \\
\hline S7 & $1.33 \pm 0.1$ & $1.32 \pm 0.2$ & $78.11 \pm 0.1$ & $23.02 \pm 0.2$ & $2.02 \pm 0.1$ & $29.38 \pm 0.1$ & $12.53 \pm 0.3$ & $32.35 \pm 0.3$ & $107.33 \pm 0.2$ \\
\hline S8 & $0.39 \pm 0.2$ & $1.45 \pm 0.1$ & $56.45 \pm 0.1$ & $33.41 \pm 0.1$ & $0.05 \pm 0.1$ & $0.76 \pm 0.1$ & $11.51 \pm 0.1$ & $39.46 \pm 0.2$ & $78.62 \pm 0.2$ \\
\hline S9 & $0.27 \pm 0.1$ & $1.05 \pm 0.2$ & $34.99 \pm 0.2$ & $22.63 \pm 0.1$ & $1.10 \pm 0.1$ & $1.49 \pm 0.2$ & $10.35 \pm 0.1$ & $44.76 \pm 0.2$ & $94.42 \pm 0.1$ \\
\hline S10 & $1.32 \pm 0.1$ & $2.55 \pm 0.1$ & $111.08 \pm 0.1$ & $30.82 \pm 0.2$ & $1.03 \pm 0.1$ & $0.75 \pm 0.1$ & $13.61 \pm 0.1$ & $45.34 \pm 0.1$ & $12.36 \pm 0.1$ \\
\hline S11 & $1.12 \pm 0.1$ & $2.23 \pm 0.1$ & $124.42 \pm 0.3$ & $28.56 \pm 0.1$ & $1.01 \pm 0.2$ & $0.12 \pm 01$ & $10.46 \pm 0.1$ & $49.22 \pm 0.1$ & $37.43 \pm 0.1$ \\
\hline S12 & $0.12 \pm 0.1$ & $2.61 \pm 0.2$ & $66.89 \pm 0.1$ & $33.78 \pm 0.2$ & $1.01 \pm 0.1$ & $0.99 \pm 0.2$ & $12.32 \pm 0.1$ & $34.04 \pm 0.1$ & $60.28 \pm 0.1$ \\
\hline S13 & $0.37 \pm 0.1$ & $0.80 \pm 0.1$ & $111.11 \pm 0.3$ & $37.99 \pm 0.1$ & $2.02 \pm 0.1$ & $0.62 \pm 0.1$ & $11.69 \pm 0.2$ & $50.62 \pm 0.2$ & $75.07 \pm 0.1$ \\
\hline S14 & $0.32 \pm 0.1$ & $2.45 \pm 0.1$ & $42.90 \pm 0.2$ & $30.22 \pm 0.1$ & $1.06 \pm 0.2$ & $1.51 \pm 0.1$ & $11.24 \pm 0.1$ & $59.11 \pm 0.1$ & $91.64 \pm 0.3$ \\
\hline S15 & $0.32 \pm 0.1$ & $1.14 \pm 0.1$ & $111.02 \pm 0.1$ & $25.52 \pm 0.1$ & $1.13 \pm 0.1$ & $0.18 \pm 0.1$ & $9.61 \pm 0.1$ & $51.02 \pm 0.1$ & $90.88 \pm 0.2$ \\
\hline
\end{tabular}

results in a review written by Orisakwe et al. (2014) on the status of metal pollution in Nigeria [a biomonitoring update - 32].

EC describes the ability of the soil to release cations and represents a crucial factor in locations polluted by metals. $\mathrm{pH}$ and $\mathrm{EC}$ are the most important factors that affect the chemical properties of soils [32]. This is because under acidic conditions metals will be released into soil water bodies. The $\mathrm{pH}$ acidic value of soils is an indication of high metal content establishment in the studied zone, which signifies weathering of the soils in the tropical regions. Soils on oil palm plantations are generally affected by the type of vegetation, agronomical factors, biological activity, and climate change [33]. High conductivity results were propably due to the significant presence of some soluble inorganic salts in the soil samples under analysis.
Acidic values of the soils and SOM confirms the presence of microbiological activities. Soil organic matter can be considered as an electron donor, which aids in the reduction reaction of metals in the presence of low $\mathrm{pH}$. Soil samples were involved in a series of biological and chemical reactions that affect their availability. Hence, the acidity of the soils was a crucial factor controlling the mobility of the metals in the soils. There was a positive correlation between metal concentrations and soil acidity, and this was in accordance with results obtained by [31-34]. In addition, abiotic and biotic factors affect the mobility and toxicity of metals. Hence $\mathrm{pH}, \mathrm{EC}$, and SOM are the limiting factors that determine the mobility and bioavailability of metals. Low $\mathrm{pH}$ values may reduce the availability of most of the nutrients available in soil to plants. This can be corrected with the use of fertilizers containing high organic matter [35].

Table 3. Mobility of heavy metals speciation showing the recovery of total metals to BCR speciation.

\begin{tabular}{|c|c|c|c|c|c|c|c|c|c|c|}
\hline S/No & Fractions (\%) & $\mathrm{Cd}$ & $\mathrm{Co}$ & $\mathrm{Cr}$ & $\mathrm{Cu}$ & $\mathrm{Fe}$ & $\mathrm{Mn}$ & $\mathrm{Pb}$ & $\mathrm{Ni}$ & $\mathrm{Zn}$ \\
\hline 1 & Exchangeable & 44.7 & 15.4 & 4.5 & 7.6 & 5.6 & 15.6 & 14.4 & 5.9 & 10.4 \\
\hline 2 & Bound to Carbonates & 4.8 & 4.9 & 7.5 & 11.9 & 10.5 & 7.3 & 6.5 & 7.2 & 9.7 \\
\hline 3 & Bound to Fe and Mn oxides & 19.6 & 26.8 & 5.1 & 5.6 & 6.5 & 34.8 & 10.8 & 16.0 & 8.5 \\
\hline 4 & Bound to Organic Matter & 25.6 & 16.5 & 7.0 & 22.2 & 2.5 & 20.7 & 24.0 & 5.9 & 7.6 \\
\hline 5 & Residual/Inert & 25.9 & 30.7 & 74.8 & 63.8 & 69.5 & 30.5 & 73.0 & 67.0 & 74.0 \\
\hline 6 & Sum of Metals (mgkg-1) & 0.26 & 2.5 & 81.7 & 33.5 & 22.1 & 4.6 & 10.9 & 30.2 & 65.1 \\
\hline 7 & Potential Mobility (\%) & 94.5 & 61.1 & 57.6 & 13.8 & 7.0 & 73.8 & 44.8 & 4.8 & 28 \\
\hline
\end{tabular}




\section{Total Metal Concentration}

Table 2 shows the mean and standard deviation values $\left(\mathrm{mgkg}^{-1}\right)$ for the total metal extraction using microwave assisted digestion method in soil from 15 locations on oil palm plantations. Plants take up metals via the soil solution, and idealy this should be reflected in environmental quality objectives. Usually environmental quality limits are based on total metal concentrations rather than the bioavailable concentrations of metals in soils. Hence total metal concentrations in soils do not present the true value because, athough they present the readily exchangeable ions, they do not include the metals that are strongly bound within the solid phases. The pollution can also be from metals loosely bound to organic matter and clays in the form of precipitates.

\section{Speciation of Metals in Soils}

Table 4 presents the mean and standard deviation values $\left(\mathrm{mgkg}^{-1}\right)$ for the various fractions of metals in soil from different locations on oil palm plantations in southern Nigeria. From the results obtained, it can be deduced that the concentrations of the different fractions vary widely at each sampling location. $\mathrm{Cd}$ is mostly abundant in the exchangeable phase in all the samples analysed in the various locations. The abundance of $\mathrm{Cd}$ in the exchangeable phase is $54.3 \%$ on Nsukka plantation. In the residual phase the concentration of $\mathrm{Cd}$ is $17.6 \%$ (Acharu plantation). It can be seen that the abundance of $\mathrm{Cd}$ in the other geochemical fractions was very low. This proves that $\mathrm{Cd}$ is more available in soil solution when compared to the other metals in all the geochemical fractions under study. The concentration of Mn was high when bound to oxides $(49.0 \%)$ in Agbarho plantation, while in the residual fraction it was $37.5 \%$ (Ago-Emokpae plantation). $\mathrm{Ni}$ in Okitipupa plantation (34.7\%) and Co in Acharu plantation (29.9\%) also showed appreciable concentrations in the $\mathrm{Fe} /$ Mn oxide fractions [36]. Metals associated with oxides experience a change in redox of the soil environment, and an increase in acidity of the soil will release the bound metals into soil solution. The concentrations of $\mathrm{Pb}$ and $\mathrm{Cu}$ were highest in the organic fraction, which is in agreement with various researchers who have done similar work on soils [14, 17, 24]. Metals in the organic phase are more released into soil solution when compared to the residual phase fractions. Lead recorded appreciable concentrations of metals in Onishere (33.8\%) and Okitipupa (28.9\%) plantations. Copper concentration was highest in Agbarho (39.3\%). Copper and lead can easily complex with organic matter because of the ease of these metals in forming organometallic compounds [37].

Metals in this phase are more available to be released into soil solution when compared to the other metals in the residual phase. Chromium and Zinc were mostly associated with the residual phase when the values of the residual phase were compared with other geochemical fractions. The plantations under study that recorded highest concentrations of $\mathrm{Cr}$ and $\mathrm{Zn}$ in the residual fractions were $87.9 \%$ (Okitipupa), $86.3 \%$ (Ikire), $82.7 \%$ (Apoje), 90.3\% (Onishere), 89.7\% (Benin City), and $85.6 \%$ (Nsukka). Lead also recorded a high concentration of metals in the residual fractions. This is in agreement with similar works by Anju et al. (2011) and Ashraf et al. (2012), who recorded similar concentrations of soil binding properties and metal concentrations [36-37]. The results of the sequential extraction show that mostly $\mathrm{Cr}$ and $\mathrm{Zn}$ were strongly bound to the residual/inert phase in all the soils under investigation. Metals in this phase are adsorbed unto the crystal lattice with secure bindings and invariable will not be released into soil solution. Changes in the dissolution of meals bound to carbonates and oxides can be seen from an anthropogenic point of view, and oxidation and reduction reactions will invariably cause the bound metals in these fractions to be released into soil solution [38-39]. Metals that present in the residual fractions are a measure of the environmental pollution of the soil in that area. High concentrations of metals in this fraction present a lower degree of pollution for metals there [40].

\section{Potential Mobility of Metals in Soils}

Potential mobility can be calculated by the difference between the sum of the concentrations of the fractions and the total concentrations. The fractions consist of potential mobile fractions, which include exchangeable, carbonate, $\mathrm{Fe}$, and $\mathrm{Mn}$ oxide and organic matter phases as shown in Table 3. The potential mobility of $\mathrm{Cd}$ is $94.5 \%$, and this is found in the exchangeable phase. This phase is comprised of the mobile and bioavailable metal phases. The metal binding is loosely held and metals are easily released into the soil solution and are readily assessible by plants. The presence of metals in this phase is the most harzardous to the environment and the ecosystem because plants easily assess such metals. As seen in Table 4, the results of our present study show that low concentrations of $\mathrm{Cr}, \mathrm{Fe}, \mathrm{Ni}$, and $\mathrm{Cu}$ were found in the exchangeable phases.

$\mathrm{Cd}$ was mostly mobile and the abundance of $\mathrm{Cd}$ as seen in Table 4 was low in the residual/inert fraction. A metal is said to be mobile when its percentage in the residual phase is low compared to the other geochemical phases. This is an indication of $\mathrm{Cd}$ being released to the environment and its toxicity [40-43]. The abundance of metals in the $\mathrm{Fe} / \mathrm{Mn}$, carbonate, and organic fractions is an indication of potential mobility. The high potential mobility of Mn in the oxide fractions is an indication that, under reducing and oxidizing conditions, bound metals to this fraction will be released. Copper and lead bound to the organic fractions also have the tendency to become mobile when the bound organic matter decomposes under the acidic conditions of the soil.

Invariably, $\mathrm{Mn}, \mathrm{Cu}$, and $\mathrm{Pb}$ will be released into soil solution and will be bioavailable to plants. These metals will be toxic to plants, the environment, and the ecosystem. Metals whose origins were anthropogenic were mainly extracted in the first steps of extraction, which was mobile steps. Mobility was reduced further when the potentially mobile metals were extracted. Anthropogenic 
Table 4. Mean and standard deviation values $\left(\mathrm{mgkg}^{-1}\right)$ for the various fractions of metals in soil from sampling locations on oil palm plantations.

\begin{tabular}{|c|c|c|c|c|c|c|c|c|c|c|}
\hline Location & Fraction & $\mathrm{Cd}$ & Co & $\mathrm{Cr}$ & $\mathrm{Cu}$ & $\mathrm{Fe}$ & Mn & $\mathrm{Pb}$ & $\mathrm{Ni}$ & $\mathrm{Zn}$ \\
\hline \multirow[t]{5}{*}{ Abak } & Exchangeable & $44.7 \pm 0.1$ & $12.7 \pm 0.1$ & $3.9 \pm 0.1$ & $8.9 \pm 0.1$ & $3.1 \pm 0.1$ & $16.3 \pm 0.1$ & $14.5 \pm 0.1$ & $7.5 \pm 0.1$ & $10.9 \pm 0.1$ \\
\hline & $\begin{array}{l}\text { Bound to } \\
\text { carbonates }\end{array}$ & $6.2 \pm 0.1$ & $12.4 \pm 0.2$ & $28.5 \pm 0.1$ & $20.1 \pm 0.1$ & $39.4 \pm 0.1$ & $7.5 \pm 0.1$ & $16.7 \pm 0.1$ & $29.7 \pm 0.2$ & $32.8 \pm 0.2$ \\
\hline & $\begin{array}{c}\text { Bound to } \mathrm{Fe} \\
\text { and Mn oxides }\end{array}$ & $18.1 \pm 0.2$ & $29.9 \pm 0.1$ & $1.5 \pm 0.1$ & $4.5 \pm 0.1$ & $4.7 \pm 0.1$ & $35.6 \pm 0.1$ & $13.9 \pm 0.1$ & $8.5 \pm 0.1$ & $9.7 \pm 0.1$ \\
\hline & $\begin{array}{c}\text { Bound to } \\
\text { organic matter }\end{array}$ & $20.5 \pm 0.1$ & $18.2 \pm 0.3$ & $9.0 \pm 0.1$ & $10.6 \pm 0.1$ & $1.8 \pm 0.1$ & $17.5 \pm 0.1$ & $22.7 \pm 0.1$ & $8.1 \pm 0.1$ & $9.2 \pm 0.1$ \\
\hline & Residual & $20.8 \pm 0.1$ & $42.3 \pm 0.2$ & $65.2 \pm 0.1$ & $69.4 \pm 0.1$ & $53.8 \pm 0.2$ & $21.1 \pm 0.1$ & $44.2 .0 \pm 0.1$ & $56.3 . \pm 0.1$ & $47.9 . \pm 0.1$ \\
\hline \multirow[t]{5}{*}{ Acharu } & Exchangeable & $49.0 \pm 0.1$ & $19.7 \pm 0.1$ & $3.0 \pm 0.1$ & $8.2 \pm 0.1$ & $5.3 \pm 0.1$ & $20.0 \pm 0.1$ & $19.6 \pm 0.1$ & $6.9 \pm 0.1$ & $13.4 \pm 0.2$ \\
\hline & $\begin{array}{l}\text { Bound to } \\
\text { carbonates }\end{array}$ & $9.3 \pm 0.1$ & $8.0 . \pm 0.1$ & $10.0 \pm 0.1$ & $17.8 \pm 0$ & $12.3 \pm 0.1$ & $12.4 \pm 0.1$ & $8.4 \pm 0.2$ & $20.4 \pm 0.1$ & $19.4 \pm 0.2$ \\
\hline & $\begin{array}{c}\text { Bound to } \mathrm{Fe} \\
\text { and Mn oxides }\end{array}$ & $18.4 \pm 0.1$ & $29.7 \pm 0.1$ & $4.8 \pm 0.2$ & $8.8 \pm 0.1$ & $3.6 \pm 0.1$ & $40.5 \pm 0.1$ & $11.4 \pm 0.1$ & $6.1 \pm 0.1$ & $9.9 \pm 0.1$ \\
\hline & $\begin{array}{c}\text { Bound to } \\
\text { organic matter }\end{array}$ & $26.5 \pm 0.2$ & $24.2 \pm 0.1$ & $28.1 \pm 0.1$ & $27.2 \pm 0.1$ & $27.4 \pm 0.1$ & $15.8 \pm 0.1$ & $23.2 \pm 0.1$ & $29.7 \pm 0.1$ & $36.6 \pm 0.1$ \\
\hline & Residual & $17.6 \pm 0.1$ & $33.8 \pm 0.1$ & $61.5 \pm 0.1$ & $48.1 \pm 0.1$ & $65.2 . \pm 0.1$ & $27.6 \pm 0.1$ & $50.6 \pm 0.1$ & $53.3 \pm 0.1$ & $43.9 \pm 0.1$ \\
\hline \multirow[t]{5}{*}{ Agbarho } & Exchangeable & $44.9 \pm 0.1$ & $16.9 \pm 0.1$ & $6.8 \pm 0.1$ & $14.6 \pm 0.1$ & $6.1 \pm 0.1$ & $13.1 \pm 0.1$ & $12.4 \pm 0.1$ & $8.8 \pm 0.2$ & $18.0 \pm 0.1$ \\
\hline & $\begin{array}{l}\text { Bound to } \\
\text { carbonates }\end{array}$ & 10.8.1士 & $16.8 \pm 0.2$ & $18.1 \pm 0.2$ & $12.6 \pm 0.2$ & $29.8 \pm 0.2$ & $12.5 \pm 0.2$ & $9.1 \pm 0.1$ & $2.6 \pm 0.3$ & $17.8 \pm 0.2$ \\
\hline & $\begin{array}{l}\text { Bound to } \mathrm{Fe} \\
\text { and Mn oxides }\end{array}$ & $18.1 \pm 0.1$ & $28.6 \pm 0.1$ & $4.6 \pm 0.1$ & $6.8 \pm 0.1$ & $5.3 \pm 0.1$ & $49.0 \pm 0.1$ & $11.7 \pm 0.3$ & $4.3 \pm 0.1$ & $7.7 \pm 0.1$ \\
\hline & $\begin{array}{c}\text { Bound to } \\
\text { organic matter }\end{array}$ & $22.4 \pm 0.1$ & $13.1 \pm 0.1$ & $22.6 \pm 0.1$ & $39.3 \pm 0.2$ & $3.4 \pm 0.1$ & $16.7 \pm 0.1$ & $19.8 \pm 0.1$ & $7.7 \pm 0.2$ & $33.2 \pm 0.1$ \\
\hline & Residual & $19.2 \pm 0.1$ & $41.9 \pm 0.1$ & $67.0 \pm 0.1$ & $54.1 \pm 0.1$ & $52.0 \pm 0.1$ & $30.9 \pm 0.2$ & $42.9 \pm 0.2$ & $70.1 \pm 0.1$ & $51.9 \pm 0.1$ \\
\hline \multirow{5}{*}{$\begin{array}{c}\text { Ago- } \\
\text { Emokpae }\end{array}$} & Exchangeable & $43.9 \pm 0.1$ & $22.7 \pm 0.4$ & $4.7 \pm 0.1$ & $6.9 \pm 0.1$ & $5.6 \pm 0.1$ & $13.7 \pm 0.1$ & $15.1 \pm 0.1$ & $7.4 \pm 0.1$ & $13.9 \pm 0.1$ \\
\hline & $\begin{array}{l}\text { Bound to } \\
\text { carbonates }\end{array}$ & $3.4 \pm 0.2$ & $2.8 \pm 0.1$ & $6.5 \pm 0.1$ & $12.6 \pm 0.1$ & $20.8 \pm 0.2$ & $15.8 \pm 0.2$ & $10.3 \pm 0.1$ & $13.7 \pm 0.1$ & $3.4 \pm 0.2$ \\
\hline & $\begin{array}{c}\text { Bound to } \mathrm{Fe} \\
\text { and Mn oxides }\end{array}$ & $18.0 \pm 0.1$ & $30.1 \pm 0.1$ & $1.8 \pm 0.1$ & $4.8 \pm 0.1$ & $6.1 \pm 0.1$ & $43.4 \pm 0.1$ & $12.3 \pm 0.1$ & $4.6 \pm 0.1$ & $2.0 \pm 0.1$ \\
\hline & $\begin{array}{c}\text { Bound to } \\
\text { organic matter }\end{array}$ & $22.5 \pm 0.1$ & $13.8 \pm 0.1$ & $29.6 \pm 0.1$ & $33.4 \pm 0.1$ & $9.6 \pm 0.1$ & $18.9 \pm 0.2$ & $12.4 \pm 0.1$ & $29.5 \pm 0.1$ & $6.5 \pm 0.1$ \\
\hline & Residual & $19.3 \pm 0.1$ & $38.7 \pm 0.1$ & $74.0 \pm 0.2$ & $54.9 .9 \pm 0.1$ & $75.1 \pm 0.2$ & $37.5 \pm 0.1$ & $44.2 \pm 0.1$ & $77.3 \pm 0.2$ & $69.4 \pm 0.1$ \\
\hline \multirow[t]{5}{*}{ Apoje } & Exchangeable & $45.1 \pm 0.1$ & $17.1 \pm 0.1$ & $3.4 \pm 0.1$ & $7.9 \pm 0.1$ & $5.7 \pm 0.1$ & $14.2 \pm 0.1$ & $13.5 \pm 0.1$ & $9.1 \pm 0.1$ & $18.9 \pm 0.1$ \\
\hline & $\begin{array}{l}\text { Bound to } \\
\text { carbonates }\end{array}$ & $5.7 \pm 0.1$ & $2.7 \pm 0.1$ & $3.8 \pm 0.1$ & $3.7 \pm 0.1$ & $12.3 \pm 0.2$ & $4.7 \pm 0.2$ & $6.5 \pm 0.1$ & $2.0 \pm 0.1$ & $2.2 \pm 0.1$ \\
\hline & $\begin{array}{l}\text { Bound to } \mathrm{Fe} \\
\text { and Mn oxides }\end{array}$ & $22.5 \pm 0.1$ & $25.0 \pm 0.1$ & $8.1 \pm 0.1$ & $1.2 \pm 0.1$ & $9.9 \pm 0.1$ & $37.1 \pm 0.1$ & $18.0 \pm 0.1$ & $2.2 \pm 0.1$ & $5.7 \pm 0.1$ \\
\hline & $\begin{array}{c}\text { Bound to } \\
\text { organic matter }\end{array}$ & $24.0 \pm 0.1$ & $12.7 \pm 0.1$ & $3.4 \pm 0.1$ & $25.7 \pm 0.1$ & $2.7 \pm 0.2$ & $19.8 \pm 0.1$ & $19.2 \pm 0.1$ & $5.3 \pm 0.3$ & $4.8 \pm 0.2$ \\
\hline & Residual & $30.3 \pm 0.1$ & $41.7 \pm 02$ & $82.7 \pm 0.1$ & $58.3 . \pm 0.2$ & $78.1 \pm 0.1$ & $32.4 \pm 0.1$ & $54.1 \pm 0.1$ & $82.3 \pm 0.1$ & $81.9 \pm 0.1$ \\
\hline \multirow[t]{5}{*}{ Badagry } & Exchangeable & $48.4 \pm 0.1$ & $12.1 \pm 0.1$ & $1.3 \pm 0.1$ & $9.1 \pm 0.1$ & $1.1 \pm 0.1$ & $16.5 \pm 0.1$ & $12.2 \pm 0.1$ & $6.2 \pm 0.1$ & $8.1 \pm 0.2$ \\
\hline & $\begin{array}{l}\text { Bound to } \\
\text { carbonates }\end{array}$ & $2.8 \pm 0.1$ & $3.7 \pm 0.2$ & $2.4 \pm 0.2$ & $4.9 \pm 0.1$ & $19.6 \pm 0.1$ & $5.9 \pm 0.2$ & $5.7 \pm 0.1$ & $4.5 \pm 0.2$ & $2.5 \pm 0.2$ \\
\hline & $\begin{array}{c}\text { Bound to Fe } \\
\text { and Mn oxides }\end{array}$ & $28.2 \pm 0.1$ & $19.5 \pm 0.1$ & $9.8 \pm 0.1$ & $5.8 \pm 0.1$ & $9.7 \pm 0.2$ & $39.7 \pm 0.1$ & $9.8 \pm 0.1$ & $3.4 \pm 0.1$ & $6.3 \pm 0.1$ \\
\hline & $\begin{array}{c}\text { Bound to } \\
\text { organic matter }\end{array}$ & $24.5 \pm 0.2$ & $19.8 \pm 0.1$ & $7.6 \pm 0.3$ & $33.7 \pm 0.2$ & $3.9 \pm 0.1$ & $18.6 \pm 0.1$ & $17.0 \pm 0.1$ & $4.1 \pm 0.1$ & $5.0 \pm 0.1$ \\
\hline & Residual & $25.2 \pm 0.1$ & $37.9 \pm 0.1$ & $82.6 \pm 0.1$ & $68.1 \pm 0.1$ & $78.3 \pm 0.1$ & $31.7 \pm 0.2$ & $44.3 \pm 0.1$ & $80.3 \pm 0.1$ & $84.3 \pm 0.1$ \\
\hline
\end{tabular}


Table 4. Continued.

\begin{tabular}{|c|c|c|c|c|c|c|c|c|c|c|}
\hline \multirow[t]{5}{*}{ Benin City } & Exchangeable & $44.2 \pm 0.1$ & $12.1 \pm 0.1$ & $3.5 \pm 0.1$ & $8.3 \pm 0.1$ & $3.4 \pm 0.1$ & $16.4 \pm 0.1$ & $14.4 \pm 0.1$ & $8.6 \pm 0.1$ & $8.8 \pm 0.1$ \\
\hline & $\begin{array}{l}\text { Bound to } \\
\text { carbonates }\end{array}$ & $3.7 \pm 0.2$ & $2.6 \pm 0.1$ & $2.3 \pm 0.2$ & $15.9 \pm 0.1$ & $2.6 \pm 0.2$ & $4.6 \pm 0.1$ & $2.5 \pm 0.1$ & $2.3 \pm 0.2$ & $3.5 \pm 0.1$ \\
\hline & $\begin{array}{l}\text { Bound to Fe } \\
\text { and Mn oxides }\end{array}$ & $19.5 \pm 0.1$ & $16.4 \pm 0.2$ & $6.2 \pm 0.3$ & $6.2 \pm 0.1$ & $5.7 \pm 0.1$ & $36.9 \pm 0.2$ & $8.8 \pm 0.1$ & $4.2 \pm 0.1$ & $7.9 \pm 0.1$ \\
\hline & $\begin{array}{c}\text { Bound to } \\
\text { organic matter }\end{array}$ & $28.7 \pm 0.1$ & $22.0 \pm 0.1$ & $5.4 \pm 0.1$ & $6.5 \pm 0.1$ & $2.1 \pm 0.1$ & $19.3 \pm 0.1$ & $22.9 \pm 0.1$ & $6.3 \pm 0.1$ & $7.3 \pm 0.2$ \\
\hline & Residual & $20.1 \pm 0.2$ & $41.9 \pm 0.1$ & $78.2 \pm 0.1$ & $66.7 \pm 0.1$ & $85.6 \pm 0.2$ & $20.8 \pm 0.3$ & $54.6 \pm 0.1$ & $82.3 \pm 0.1$ & $89.7 \pm 0.1$ \\
\hline \multirow{5}{*}{$\begin{array}{l}\text { Igede- } \\
\text { Ekiti }\end{array}$} & Exchangeable & $47.9 \pm 0.1$ & $11.1 \pm 0.1$ & $3.4 \pm 0.1$ & $7.3 \pm 0.1$ & $6.5 \pm 0.1$ & $18.1 \pm 0.1$ & $13.2 \pm 0.1$ & $4.1 \pm 0.1$ & $9.7 \pm 0.1$ \\
\hline & $\begin{array}{l}\text { Bound to } \\
\text { carbonates }\end{array}$ & $2.9 \pm 0.1$ & $3.2 \pm 0.1$ & $12.4 \pm 0.2$ & $5.4 \pm 0.1$ & $10.4 \pm 0.1$ & $3.7 \pm 0.1$ & $4.8 \pm 0.2$ & $6.2 \pm 0.1$ & $4.2 \pm 0.1$ \\
\hline & $\begin{array}{c}\text { Bound to } \mathrm{Fe} \\
\text { and Mn oxides }\end{array}$ & $22.7 \pm 0.1$ & $17.3 \pm 0.1$ & $6.4 \pm 0.1$ & $9.6 \pm 0.1$ & $3.6 \pm 0.1$ & $27.9 \pm 0.1$ & $2.6 \pm 0.1$ & $3.2 \pm 0.1$ & $8.5 \pm 0.1$ \\
\hline & $\begin{array}{c}\text { Bound to } \\
\text { organic matter }\end{array}$ & $26.2 \pm 0.2$ & $17.5 \pm 0.1$ & $8.3 \pm 0.1$ & $6.8 \pm 0.1$ & $2.6 \pm 0.1$ & $18.7 \pm 0.1$ & $22.9 \pm 0.1$ & $2.7 \pm 0.1$ & $9.2 \pm 0.1$ \\
\hline & Residual & $38.3 \pm 0.1$ & $33.3 \pm 0.2$ & $59.8 \pm 0.1$ & $76.0 \pm 0.3$ & $76.5 \pm 0.1$ & $30.9 \pm 0.1$ & $50.3 \pm 0.1$ & $82.8 \pm 0.2$ & $78.4 \pm 0.1$ \\
\hline \multirow[t]{5}{*}{ Ikire } & Exchangeable & $49.5 \pm 0.1$ & $12.8 \pm 0.1$ & $2.2 \pm 0.1$ & $6.8 \pm 0.1$ & $3.9 \pm 0.1$ & $14.7 \pm 0.1$ & $13.0 \pm 0.1$ & $9.2 \pm 0.1$ & $6.3 \pm 0.1$ \\
\hline & $\begin{array}{l}\text { Bound to } \\
\text { carbonates }\end{array}$ & $12.4 \pm 0.1$ & $3.6 \pm 0.1$ & $4.7 \pm 0.1$ & $12.5 \pm 0.1$ & $12.9 \pm 0.1$ & $2.6 \pm 0.1$ & $2.7 \pm 0.1$ & $2.3 \pm 0.1$ & $7.0 \pm 0.2$ \\
\hline & $\begin{array}{l}\text { Bound to Fe } \\
\text { and Mn oxides }\end{array}$ & $16.1 \pm 0.1$ & $23.1 \pm 0.1$ & $3.7 \pm 0.1$ & $7.1 \pm 0.1$ & $5.7 \pm 0.1$ & $27.1 \pm 0.1$ & $5.2 \pm 0.2$ & $7.8 \pm 0.1$ & $5.1 \pm 0.1$ \\
\hline & $\begin{array}{c}\text { Bound to } \\
\text { organic matter }\end{array}$ & $25.7 \pm 0.3$ & $16.2 \pm 0.1$ & $4.9 \pm 0.1$ & $28.2 \pm 0.1$ & $27.4 \pm 0.1$ & $26.4 \pm 0.1$ & $27.8 \pm 0.1$ & $2.0 \pm 0.1$ & $9.8 \pm 0.2$ \\
\hline & Residual & $29.3 \pm 0.1$ & $33.1 \pm 0.2$ & $86.3 \pm 0.2$ & $67.2 \pm 0.1$ & $62.6 \pm 0.1$ & $34.9 \pm 0.2$ & $50.9 \pm 0.1$ & $95.3 \pm 0.3$ & $80.2 \pm 0.1$ \\
\hline \multirow[t]{5}{*}{ Iresa-apa } & Exchangeable & $45.2 \pm 0.1$ & $13.2 \pm 0.1$ & $4.6 \pm 0.1$ & $7.8 \pm 0.1$ & $4.2 \pm 0.1$ & $14.0 \pm 0.1$ & $13.5 \pm 0.1$ & $6.4 \pm 0.1$ & $6.7 \pm 0.1$ \\
\hline & $\begin{array}{l}\text { Bound to } \\
\text { carbonates }\end{array}$ & $2.4 \pm 0.1$ & $3.9 \pm 0.2$ & $5.7 \pm 0.1$ & $3.8 \pm 0.1$ & $4.4 \pm 0.2$ & $5.3 \pm 0.2$ & $7.3 \pm 0.2$ & $3.2 \pm 0.1$ & $4.5 \pm 0.1$ \\
\hline & $\begin{array}{c}\text { Bound to } \mathrm{Fe} \\
\text { and Mn oxides }\end{array}$ & $18.6 \pm 0.1$ & $24.4 \pm 0.1$ & $9.0 \pm 0.1$ & $3.1 \pm 0.1$ & $8.1 \pm 0.1$ & $22.7 \pm 0.1$ & $8.6 \pm 0.1$ & $29.9 \pm 0.1$ & $4.8 \pm 0.1$ \\
\hline & $\begin{array}{c}\text { Bound to } \\
\text { organic matter }\end{array}$ & $23.9 \pm 0.1$ & $15.5 \pm 0.1$ & $6.7 \pm 0.1$ & $22.9 \pm 0.1$ & $1.8 \pm 0.1$ & $29.6 \pm 0.1$ & $24.2 \pm 0.1$ & $3.2 \pm 0.1$ & $7.3 \pm 0.1$ \\
\hline & Residual & $25.9 \pm 0.1$ & $26.2 \pm 0.1$ & $79.3 \pm 0.2$ & $70.4 \pm 0.1$ & $74.8 \pm 0.1$ & $21.8 \pm 0.1$ & $41.9 \pm 0.3$ & $62.3 \pm 0.2$ & $77.8 \pm 0.3$ \\
\hline \multirow[t]{5}{*}{ Nsukka } & Exchangeable & $54.2 \pm 0.1$ & $14.9 \pm 0.1$ & $3.2 \pm 0.1$ & $5.7 \pm 0.1$ & $7.1 \pm 0.1$ & $17.0 \pm 0.1$ & $12.5 \pm 0.1$ & $3.5 \pm 0.1$ & $9.6 \pm 0.1$ \\
\hline & $\begin{array}{l}\text { Bound to } \\
\text { carbonates }\end{array}$ & $4.6 \pm 0.2$ & $3.3 \pm 0.2$ & $5.3 \pm 0.1$ & $9.3 \pm 0.2$ & $3.7 \pm 0.2$ & $6.5 \pm 0.2$ & $3.0 \pm 0.1$ & $5.2 \pm 0.1$ & $8.0 \pm 0.1$ \\
\hline & $\begin{array}{c}\text { Bound to Fe } \\
\text { and Mn oxides }\end{array}$ & $15.9 \pm 0.1$ & $23.4 \pm 0.1$ & $4.5 \pm 0.1$ & $3.2 \pm 0.3$ & $9.8 \pm 0.1$ & $35.8 \pm 0.1$ & $8.6 \pm 0.1$ & $27.3 \pm 0.1$ & $7.2 \pm 0.1$ \\
\hline & $\begin{array}{c}\text { Bound to } \\
\text { organic matter }\end{array}$ & $27.9 \pm 0.1$ & $16.1 \pm 0.2$ & $9.1 \pm 0.1$ & $26.6 \pm 0.1$ & $37.3 \pm 0.1$ & $23.2 \pm 0.2$ & $27.0 \pm 0.1$ & $9.4 \pm 0.1$ & $7.5 \pm 0.1$ \\
\hline & Residual & $25.7 \pm 0.2$ & $24.3 \pm 0.1$ & $80.2 \pm 0.1$ & $47.3 \pm 0.1$ & $61.4 \pm 0.1$ & $38.3 \pm 0.1$ & $67.3 \pm 0.1$ & $59.9 \pm 0.1$ & $85.6 \pm 0.1$ \\
\hline \multirow[t]{5}{*}{ Okitipupa } & Exchangeable & $44.5 \pm 0.1$ & $14.6 \pm 0.1$ & $8.3 \pm 0.1$ & $6.0 \pm 0.1$ & $4.9 \pm 0.1$ & $14.9 \pm 0.1$ & $12.0 \pm 0.1$ & $1.5 \pm 0.1$ & $9.3 \pm 0.1$ \\
\hline & $\begin{array}{l}\text { Bound to } \\
\text { carbonates }\end{array}$ & $3.2 \pm 0.1$ & $1.2 \pm 0.1$ & $3.8 \pm 0.2$ & $1.3 \pm 0.1$ & $3.3 \pm 0.2$ & $4.8 \pm 0.2$ & $2.8 \pm 0.1$ & $1.4 \pm 0.2$ & $3.9 \pm 0.2$ \\
\hline & $\begin{array}{c}\text { Bound to Fe } \\
\text { and Mn oxides }\end{array}$ & $27.8 \pm 0.1$ & $29.0 \pm 0.1$ & $5.7 \pm 0.1$ & $3.4 \pm 0.1$ & $8.6 \pm 0.1$ & $38.2 \pm 0.1$ & $7.1 \pm 0.1$ & $34.7 \pm 0.1$ & $5.5 \pm 0.1$ \\
\hline & $\begin{array}{c}\text { Bound to } \\
\text { organic matter }\end{array}$ & $33.4 \pm 0.1$ & $18.6 \pm 0.1$ & $3.0 \pm 0.1$ & $28.9 \pm 0.1$ & $1.1 \pm 0.1$ & $23.7 \pm 0.1$ & $27.6 \pm 0.1$ & $68.8 \pm 0.1$ & $6.7 \pm 0.1$ \\
\hline & Residual & $29.7 \pm 0.1$ & $18.7 \pm 0.1$ & $87.9 \pm 0.2$ & $70.4 \pm 0.1$ & $55.7 \pm 0.1$ & $37.9 \pm 0.1$ & $55.1 \pm 0.1$ & $44.8 \pm 0.1$ & $62.1 \pm 0.1$ \\
\hline
\end{tabular}


Table 4. Continued.

\begin{tabular}{|c|c|c|c|c|c|c|c|c|c|c|}
\hline \multirow[t]{5}{*}{ Onishere } & Exchangeable & $41.9 \pm 0.1$ & $13.7 \pm 0.1$ & $8.6 \pm 0.2$ & $4.7 \pm 0.1$ & $7.8 \pm 0.1$ & $12.1 \pm 0.2$ & $16.3 \pm 0.1$ & $1.9 \pm 0.1$ & $7.0 \pm 0.1$ \\
\hline & $\begin{array}{l}\text { Bound to } \\
\text { carbonates }\end{array}$ & $1.3 \pm 0.2$ & $1.7 \pm 0.1$ & $1.3 \pm 0.1$ & $2.1 \pm 0.1$ & $1.3 \pm 0.3$ & $2.5 \pm 0.2$ & $1.9 \pm 0.2$ & $1.1 \pm 0.1$ & $1.9 \pm 0.1$ \\
\hline & $\begin{array}{l}\text { Bound to Fe } \\
\text { and Mn oxides }\end{array}$ & $15.6 \pm 0.1$ & $33.8 \pm 0.2$ & $5.1 \pm 0.1$ & $5.9 \pm 0.1$ & $3.4 \pm 0.1$ & $35.8 \pm 0.1$ & $5.9 \pm 0.1$ & $33.1 \pm 0.1$ & $8.1 \pm 0.1$ \\
\hline & $\begin{array}{c}\text { Bound to } \\
\text { organic matter }\end{array}$ & $23.2 \pm 0.1$ & $12.7 \pm 0.1$ & $2.7 \pm 0.1$ & $6.8 \pm 0.1$ & $3.2 \pm 0.3$ & $22.7 \pm 0.1$ & $33.8 \pm 0.1$ & $6.6 \pm 0.1$ & $2.4 \pm 0.1$ \\
\hline & Residual & $24.1 \pm 0.1$ & $20.0 \pm 0.1$ & $77.2 \pm 0.1$ & $82.1 \pm 0.1$ & $65.3 \pm 0.1$ & $32.8 \pm 0.1$ & $54.8 . \pm 0.2$ & $76.3 \pm 0.3$ & $90.3 \pm 0.1$ \\
\hline \multirow[t]{5}{*}{ Ubiaja } & Exchangeable & $38.7 \pm 0.1$ & $15.8 \pm 0.1$ & $7.9 \pm 0.1$ & $5.1 \pm 0.3$ & $6.2 \pm 0.1$ & $15.2 \pm 0.1$ & $14.6 \pm 0.1$ & $3.7 \pm 0.1$ & $5.9 \pm 0.1$ \\
\hline & $\begin{array}{l}\text { Bound to } \\
\text { carbonates }\end{array}$ & $1.4 \pm 0.2$ & $4.9 \pm 0.2$ & $4.3 \pm 0.2$ & $3.8 \pm 0.2$ & $2.3 \pm 0.3$ & $3.9 \pm 0.2$ & $2.8 \pm 0.1$ & $5.9 \pm 0.1$ & $3.2 \pm 0.2$ \\
\hline & $\begin{array}{l}\text { Bound to } \mathrm{Fe} \\
\text { and Mn oxides }\end{array}$ & $17.1 \pm 0.1$ & $33.0 \pm 0.1$ & $2.1 \pm 0.1$ & $8.2 \pm 0.1$ & $6.8 \pm 0.1$ & $33.4 \pm 0.1$ & $5.5 \pm 0.2$ & $33.2 \pm 0.1$ & $5.0 \pm 0.2$ \\
\hline & $\begin{array}{c}\text { Bound to } \\
\text { organic matter }\end{array}$ & $28.6 \pm 0.2$ & $19.4 \pm 0.2$ & $9.9 \pm 0.1$ & $28.0 \pm 0.1$ & $2.4 \pm 0.2$ & $18.7 \pm 0.1$ & $30.7 \pm 0.1$ & $9.0 \pm 0.1$ & $2.6 \pm 0.1$ \\
\hline & Residual & $37.4 \pm 0.1$ & $26.5 \pm 0.1$ & $66.4 \pm 0.1$ & $55.3 \pm 0.2$ & $61.3 \pm 0.1$ & $38.4 \pm 0.1$ & $49.8 \pm 0.1$ & $76.3 \pm 0.1$ & $84.0 \pm 0.1$ \\
\hline \multirow[t]{5}{*}{ Umuabi } & Exchangeable & $35.4 \pm 0.1$ & $21.3 \pm 0.1$ & $3.1 \pm 0.1$ & $6.0 \pm 0.1$ & $6.5 \pm 0.1$ & $17.2 \pm 0.1$ & $19.7 \pm 0.1$ & $4.1 \pm 0.3$ & $9.6 \pm 0.1$ \\
\hline & $\begin{array}{l}\text { Bound to } \\
\text { carbonates }\end{array}$ & $1.6 \pm 0.2$ & $2.4 \pm 0.1$ & $3.3 . \pm 0.2$ & $1.6 \pm 0.1$ & $2.1 \pm 0.1$ & $1.0 \pm 0.2$ & $7.2 \pm 0.2$ & $2.2 \pm 0.1$ & $2.8 \pm 0.1$ \\
\hline & $\begin{array}{l}\text { Bound to } \mathrm{Fe} \\
\text { and Mn oxides }\end{array}$ & $17.5 \pm 0.2$ & $38.6 \pm 0.1$ & $2.8 \pm 0.1$ & $4.7 \pm 0.2$ & $8.0 \pm 0.3$ & $18.7 \pm 0.1$ & $33.0 \pm 0.2$ & $37.5 \pm 0.1$ & $33.1 \pm 0.1$ \\
\hline & $\begin{array}{c}\text { Bound to } \\
\text { organic matter }\end{array}$ & $27.0 \pm 0.1$ & $18.1 \pm 0.1$ & $5.5 \pm 0.1$ & $8.2 \pm 0.1$ & $2.9 \pm 0.1$ & $24.6 \pm 0.1$ & $28.6 \pm 0.1$ & $5.4 \pm 0.1$ & $6.5 \pm 0.1$ \\
\hline & Residual & $25.8 \pm 0.1$ & $9.7 \pm 0.1$ & $76.3 \pm 0.1$ & $73.9 \pm 0.1$ & $96.9 \pm 0.2$ & $21.2 \pm 0.1$ & $50.8 \pm 0.2$ & $98.5 \pm 0.2$ & $76.3 \pm 0.1$ \\
\hline
\end{tabular}

sources were mostly from crude oil exploration and spillage, urbanization, and industrialization. $\mathrm{Zn}$ and $\mathrm{Ni}$ were relatively immobile and probably were extracted in the residual or inert phases. This comprises the lithogenic regions of the environment.

The potential mobility of the metals with high fractions in the residual phase is as follows: $\mathrm{Cr}(74.8 \%), \mathrm{Zn}(74.0 \%)$, $\mathrm{Pb}(73 \%), \mathrm{Fe}(69.5 \%)$, Ni (67.0\%), Cu (63.8\%), Mn (30.5\%), Co (30.7\%), and Cd $(25.9 \%)$. These values were high when compared to the values of other metals in the other mobile and potentially mobile fractions. This is in agreement with various researchers, who have conducted similar studies. Mobility and mobility are affected by various soil properties and the values of $\mathrm{pH}, \mathrm{EC}$, and SOM showed a positive correlation with metal contents and speciation, and this agrees with researchers who have conducted similar studies [11, 36-37].

Metal speciation is of importance in the mobility of the metals in the soil solution. Metals in complex forms are less toxic to plants and animals as compared to metals in the free ion state. Metals that are complexed are not readily available for uptake by plants and soil organisms. Total metal analysis is useful for determining the horizontal and vertical pollution of the soils sampled in a particular area and does not give a measure of the bioavalibility of these metals to plants and animals nor its speciation. Neither does it give a measure of the available nutrients or toxicity of such nutrients. The extraction of total metal in the samples using a mixture of acids probably leaches metals that are exchangeable or from a pollution source, which is very recent. Pollution can also be from metals loosely bound to organic matter and clays in the form of precipitates [41-43].

The distinctions between these soil properties are unclear, but are mostly controlled by soil $\mathrm{pH}$. Redox reactions play a major role in the biotransformation of the reactions of iron and manganese oxides in soils. The sinks for metals are their potentially active role in clays, minerals, and manganese oxides, which affect the geology of the soil. Bound metals are frequently found in the organic fractions and can be released into soil solution by the decomposition and recycling of organic matter. Microorganisms play an active role in decreasing the mobility and hence toxicity of some metals by reducing very toxic metals to less toxic forms, and hence their mobility and toxicity is limited [36-38]. Generally, metals with high binding capacities are available in low concentrations for soil organisms and transport into freshwater systems. Plant uptake of metals presents the primary entry into the food chain. This is dependent on the translocation of metals from soils to plants via the root hairs and epidermal cells. Subsequently, the metals are translocated via the xylem to the shoots and stored in the storage tissues, which is practically food to man and animals. These processes are controlled by soil factors though chemical speciation, and fractionation also has a role to play in the bioavailability of metals in soil. 
The movement of metals in soils has the potential to primarily depend on the speciation of the metal. Sequential extraction procedures have been used to selectively remove metals at each extraction stage. Although the procedures cannot identify the actual form of the metal, it selectively classifies them into exchangeable metals, metals bound to carbonates, metals bound to iron and manganese oxides, metals bound to organic matter, and metals bound to the residual fraction. The exchangeable fraction is of paramount importance when considering the movement of metal ions in soil solution. This fraction represents the potentially mobile fraction of the metals and the mobility of these metals decreases in accordance with the sequence of extraction. Theoretically, mild chemicals can extract metals that are easily released into soil solution as compared to those ions that are strongly adsorbed into crystalline lattices or precipitated. Oxides help in cementing metals together. Under reducing and acidic conditions, oxides can be mobilized and release the bound metals into soil solution. The organic fraction is stable to some extent but can also be oxidized by the decomposition of organic matter, which releases the bound metals [11-20].

\section{Mobile Element}

\section{Cadmium (Cd)}

In the speciation studies, the concentration of $\mathrm{Cd}$ was high in all the plantations. This was above the standard regulatory limits/background levels of metals in soil in the environment, which was $0.5 \mathrm{mgkg}^{-1}$. Phosphate rock fertilizer is extensively used on oil palm plantations and is a major contributor of cadmium to agricultural soils [5]. Plants - especially oil palms in soils polluted with metals - can accumulate high concentrations of such metals since the oil palm tree is used in bioremediation of polluted soils. The results obtained in this study were in agreement with Okoronkwo et al. (2005), who investigated elevated concentrations of metals and its accumulated consequence on urban refuse and sewage disposal on a site used for agriculture in Abakaliki, Nigeria, and Iwegbue (2011), who determined Cd pollution in Nigerian soils [15, 24].

Elevated levels of $\mathrm{Cd}$ in soil under investigation could probably be because of unwholesome farm practices, such as the use of Cd-containing fertilizers and insecticides. Other unwholesome practices include the burning of bushes and forest fires. Redox potential of sedimentwater systems can also be a factor that exerts controlling regulation on the chemical association of particulate $\mathrm{Cd}$, where $\mathrm{pH}$ and salinity affect the stability of its various forms [43]. In anoxic environments, particulate $\mathrm{Cd}$ usually complexes with insoluble organic matter or that bound to sulfide minerals. Oxidation of reduced sediment or exposure to an acidic environment will result in the transformation of the insoluble sulfide-bound cadmium into more mobile and potentially bioavailable hydroxide, carbonate, and exchangeable forms.
Studies of lake and fluvial sediment indicate that most $\mathrm{Cd}$ bound to exchangeable sites, carbonate fraction, and iron-manganese oxide minerals can be exposed to chemical changes at the sediment-water interface and are susceptible to remobilization in water [22-24]. In oxidized, near neutral water, $\mathrm{CdCO}$ limits the solubility of $\mathrm{Cd}^{2+}[22-24]$. Since cadmium was the most available and assessable metal in the four fractions, it invariably shows that $\mathrm{Cd}$ is mostly found in the soluble fraction or the non-residual fractions, and not the insoluble or residual fractions. It was the most available metal in soils studied and therefore mainly bound to the acid soluble and carbonate fractions. This demonstrates that $\mathrm{Cd}$ is easily available in the soil and transferable to humans through the food chain. Intensive review has been conducted on the toxic effect of $\mathrm{Cd}$ in the environment because it is an experimental animal carcinogen $[22,24,44]$. Natural and anthropogenic sources of $\mathrm{Cd}$ in the environment could be from the weathering of rocks, volcanoes, and bush fires. Effects of $\mathrm{Cd}$ in humans include osteomalacia, pulmonary emphysema, infertility, and renal tubular damage [45].

\section{Fairly Mobile Elements}

$$
\text { Cobalt (Co) }
$$

In the speciation studies, the concentrations of Co were also high in all the plantations investigated. The value was highest in Acharu plantation, which was above $8 \mathrm{mgkg}^{-1}$ - the maximum permissible limit for Co in polluted soil. The values obtained on all the plantations were above the standard regulatory limits/background levels Co in soil in the environment. This essential metal becomes toxic at elevated concentrations [46]. Natural factors such as Co occurrence in seawater, volcanic eruptions, and forest fires contribute to the concentration of $\mathrm{Co}$ in the environment [46]. Some forms of Co are also radioactive [47]. Contamination of soils by $\mathrm{Co}$ in investigated soils could also be from effluents and runoff where indiscrimate disposal of porcelain-clad casseroles and paints have been discarded. Symptoms of Co poisoning in humans are vomiting/nausea; eye, heart, and thyroid gland damage; sterility; hair loss; diarrhea; and even death. Other effects of high concentrations of Co may be manifested by signs such as skin and breathing disorders. Co is also known to cause some forms of cancer [48].

$$
\text { Lead }(\mathrm{Pb})
$$

In speciation studies the concentrations of $\mathrm{Pb}$ were high in all the plantations, but recorded the highest concentration $n$ Nsukka. The maximum permissible limit of $\mathrm{Pb}$ in the environment is $10 \mathrm{mgkg}^{-1}$. The results of the study agree with those obtained by Ajala and Onwukeme, who conducted speciation studies in flood plain soils of Eke-Mgbom Efikpo, Nigeria [27]. The concentration of $\mathrm{Pb}$ found in the soil was high and was basically in the exchangeable fractions. Soluble $\mathrm{Pb}$, which is dissolved 
in soil, is bound to organic matter and carbonates. This greatly reduces the solubility and mobility of $\mathrm{Pb}$ in soils making it strongly held by soil constituents to a greater degree. High concentrations can be harmful, leading to blood and nervous system disorders, kidney damage, diarrhea, infertility, miscarriages, and lethargy [49]. $\mathrm{Pb}$ in the environment can be from sources such as the exhaust pipes of petrol engines, bitumen, and lead acid battery recycling. Soils may also be contaminated with $\mathrm{Pb}$ when located close to $\mathrm{Pb}$ mines, glass factories, pesticides, fertilizers, smelting operations, and the combustion of fossil fuels.

Organic and inorganic lead compounds - especially from mines - may pose serious health risks to all forms of life [50-51]. Lead was less mobile when compared to $\mathrm{Cd}$. Ingestion of $\mathrm{Pb}$ via food in humans has a tendency to cause nervous disorders, blood cancer, and decreased fertility, among other factors [49].

\section{Manganese (Mn)}

The concentration of Mn was not above the standard permissable level in soil. This is of importance because Mn is an essential metal with antioxidant properties beneficial to plants and animals [50-51]. This functions in the mitochondria providing oxygen to the cells. Mn enzymes are active in the metabolism of food, such as proteins and lipids. Mn is also a co-factor in the active sites of enzymes such as glycosyltransferases and prolidase, which are responsible for the development of strong bones, tissue, and cartilage production $[52,53]$. Although an essential metal, it can be toxic at elevated concentrations and it plays an important role in enzyme synthesis [53].

\section{Chromium (Cr)}

The total metal concentrations of $\mathrm{Cr}$ in our study were slightly above the maximum permissible levels for $\mathrm{Cr}$ in soils. The plantations, which recorded high levels of $\mathrm{Cr}$, were Abak, Badagry, Iresa-apa, Okitipupa, and Umuabi. Okitipupa recorded the highest concentration of $\mathrm{Cr}$ at $111.02 \mathrm{mgkg}^{-1}$, while the maximum permissible limit of $\mathrm{Cr}$ in soils is $100 \mathrm{mgkg}^{-1}$. In the speciation studies, $\mathrm{Cr}$ was associated with the residual phase. Metals in this phase are less mobile compared to $\mathrm{Cd}$ and are usually associated with the lithogenic phase. The results were in agreement with studies conducted by Osu et al. in a speciation study [26]. They studied the distribution of metals in the soils of an automobile workshop. The toxicity of metals depends on the present oxidation states. For instance, $\mathrm{Cr}$ (VI) is a known carcinogen and toxic to plants and animals [53], whereas when $\mathrm{Cr}(\mathrm{VI})$ is reduced to $\mathrm{Cr}$ (III), $\mathrm{Cr}$ (III) becomes useful for plant nutrition and is of great importance. Cr (VI) is mobile under acidic conditions and hence bioavailable to plants. The high value of organic matter and sulphides in the soils is also a contributory factor to the immobility of $\mathrm{Cr}$ (III) because it forms organic complexes with $\mathrm{Cr}$ (III) when it is reduced, making it unavailable for plant nutrition.
$\mathrm{Cr}$ is one of the essential elements needed in trace amounts that prominently takes part in metabolism. It is required in enzyme activity and acts as a cofactor in the regulation of sugar levels in the body. High levels of $\mathrm{Cr}$ are toxic, especially $\mathrm{Cr} \mathrm{VI}$, which is known to be more toxic and carcinogenic when compared to $\mathrm{Cr}$ III. Symptoms of acute $\mathrm{Cr}$ toxicity are related to convulsion, and respiratory and stomach disorders. Improper disposal of electronic waste and the illicit disposal of used oils and automobile waste have contributed to increases in the concentration of $\mathrm{Cr}$ in most plantations [54]. It has high antioxidant properties, which is crucial for carbohydrate metabolism, and the prevention of some forms of diabetes and cardiovascular diseases.

High consumption of Cr-containing foods may lead to gastrointestinal and blood disorders and convulsions. Research has proven that cancer of the respiratory tract is common in occupational settings where a high concentration of $\mathrm{Cr}$ is prevalent [22].

\section{Copper $(\mathrm{Cu})$}

Most of the plantations recorded elevated levels of $\mathrm{Cu}$, but the highest concentration was recorded in Badagry with a value of $61.11 \mathrm{mgkg}^{-1}$. $\mathrm{Cu}$ is usually held in soils through adsorption and exchange processes. It is an essential element possessing antioxidant properties that protect organs in animals and plants against free radicals. It is a component of hemoglobin, ferroxidase, tyrosine, cytochrome oxidase, and ascorbic acid oxidase. Coupled with vitamin C, these enzymes help in the proper functioning of the organs and carbohydrate metabolism.

Under elevated concentrations $\mathrm{Cu}$ becomes toxic to plants and animals. The total metal concentrations were high coupled with a factor; $\mathrm{Cu}$ was bound to the organic fraction in soils in our study. Invariably, $\mathrm{Cu}$ in these soils poses toxicity and environmental risks [55]. Plants need $\mathrm{Cu}$ for the production of chlorophyll and proteins and for various biochemical processes. Concentrations of $\mathrm{Cu}$ in our study were toxic and lethal [56]. Symptoms of $\mathrm{Cu}$ toxicity include liver and kidney damage, nausea, and diarrhea.

Although $\mathrm{Cu}$ occurs naturally in the environment, the concentrations were small compared to the anthropogenic sources. Anthropogenic sources of $\mathrm{Cu}$ in our study may be from the random use of $\mathrm{Cu}$ pesticides. The indiscriminate disposal of electronic waste found in household and industrial appliances is also a major contributor of $\mathrm{Cu}$ pollution in these soils [57].

\section{Iron $(\mathrm{Fe})$}

The total metal concentrations in all the plantations as seen in Table 2 were below the maximum permissible limits for Fe in soils. An exception was Acharu plantation, which recorded a concentration of $40 \mathrm{mgkg}^{-1}$. The maximum permissible level for Fe in soils is $38 \mathrm{mgkg}^{-1}$. Fe is a very essential element, especially in cells, for the production of hemoglobin. It promotes strong mental alertness. $\mathrm{Fe}$ is an 
essential element that is toxic at elevated concentrations. Symptoms of $\mathrm{Fe}$ toxicity are manifested in oxidative stress and metabolic disorders. In plants, symptoms of Fe deficiency are manifested in stunted growth and eventual death of the plant. [58].

Natural sources of Fe in the plantation under study may be from the weathering of rocks, mica and clay. An anthropogenic source of Fe in Acharu may be from the Fe smelting company in the vicinity of the plantation. Contamination may also be from industries involved in the casing of wells, pipes, and pumps [59]. Other sources of iron contamination of soils could be from the effluents of acid mines, drainage, and landfills located near the plantation [60].

\section{Immobile Elements}

\section{Zinc (Zn)}

Total concentrations of $\mathrm{Zn}$ in all the plantations under study as seen in Table 2 were below the maximum permissible levels of $\mathrm{Zn}$ in soils. The exceptions were for Apoje, Badagry, Benin City, Ikire, Ubiaja, and Umuabi plantations, which recorded about $92 \mathrm{mgkg}^{-1}$, $96 \mathrm{mgkg}^{-1}, 107 \mathrm{mgkg}^{-1}$, $94 \mathrm{mgkg}^{-1}$, $91 \mathrm{mgkg}^{-1}$, and $91 \mathrm{mgkg}^{-1}$, respectively. The maximum permissible levels of $\mathrm{Zn}$ in soils is 90 and these plantations recorded slightly higher concentrations of $\mathrm{Zn}$ above the permissible limits.

Total $\mathrm{Zn}$ in contaminated soils was associated with the residual fractions. $\mathrm{Zn}$ is an essential element with high antioxidant properties, which protects the actions of free radicals. It is required for metabolism of cells, DNA, and development of the foetus. A deficiency of the essential element in the diet may cause growth and reproductive disorders, nausea, and lethargy [61]. Zn can be released into soil solution from the bound crystalline lattice in acidic environments. High concentrations of soluble $\mathrm{Zn}$ are available in oxidized conditions and at $\mathrm{pH} 5$ to 6.5 , whereas low abundances of soluble $\mathrm{Zn}$ will be at a $\mathrm{pH}$ of eight.

In polluted river environments $\mathrm{Zn}$ is less mobile than cadmium (and perhaps less mobile than lead). The bioavailability of $\mathrm{Zn}$ may depend on factors such as chemical, biological, and environmental processes. These processes may include time and the action of microorganisms and $\mathrm{pH}$, as bound $\mathrm{Zn}$ can be released to soil solution for plant uptake [62-63].

\section{Nickel (Ni)}

The total metal concentrations of $\mathrm{Ni}$ in most of the plantations under study as seen in Table 2 were above the maximum permissible levels of $\mathrm{Ni}$ in soils. The plantations were Abak, Badagry, Ikire, Iresa-apa, Nsukka, Okitipupa, Ubiaja, and Umuabi, which recorded $\mathrm{Ni}$ concentations of about $41 \mathrm{mgkg}^{-1}, 49 \mathrm{mgkg}^{-1}$, $44 \mathrm{mgkg}^{-1}, 45 \mathrm{mgkg}^{-1}, 49 \mathrm{mgkg}^{-1}, 50 \mathrm{mgkg}^{-1}$, and $59 \mathrm{mgkg}^{-1}$, respectively. The maximum permissible level of $\mathrm{Ni}$ in soils is 40 , and the mentioned plantations recorded slightly higher concentrations of $\mathrm{Ni}$.

Nickel in Okitipupa plantation showed appreciable concentrations of $29.9 \%$ and $68.8 \%$ in the $\mathrm{Fe} / \mathrm{Mn}$ oxide and organic matter fractions, respectively. Materials containing Ni play an important role in our daily lives through electronics, batteries, mobile phones, preparation of food, equipment manufacturing, transportation, infracstructure, energy generation, etc.

$\mathrm{Ni}$ is a metal of interest in industry because of its excellent anticorrosion properties and tensile strength. It is an excellent choice in alloy manufacture, especially in the manufacture of stainless steel, and it is also an esential element required by humans for healthy growth. It is a constituent of enzymes and proteins and also is required for the absorption of iron. It is also essential for seed germination and improves crop yield since it is used as a component of fertilizers. A minute concentration of $\mathrm{Ni}$ is naturally found in rocks and soils in the environment. Anthropogenic sources of $\mathrm{Ni}$ in the plantations under study were probably from forest fires, fertilizers, industrial wastes and sludge, and nuclear power. Effluents from electroplating, electronics and metal manufacturing industries may also contain high levels of Ni ions.

Although $\mathrm{Ni}$ is an essential element it is toxic at elevated concentrations that can result in organ damage, skin and pulmonary lesions, allergies, and some forms of cancer. In plants, acute toxicity results in such signs as leaf necrosis, stunted growth, low yield, and general plant deformation [64].

\section{Conclusion}

Oil from the palm fruit has a considerable concentration of vitamins A, C, and E. Palm oil has been shown by researchers to have the potential to cure some forms of cancer and heart disease. A biomonitoring update on a review written by Orisakwe et al. (2014) on Nigerian soils revealed that millions people die each year in the 46 African countries due to environmental risk factors of which metal pollution is the highest. Due to the importance of the oil palm tree and the fact that Nigerian soils are polluted, the speciation, bioavailability, and mobility of metals in soils from selected states on oil palm plantations in southwest Nigeria were investigated. But knowledge about the total concentrations of metals alone is not adequate to evaluate the environmental effects of metals in soils. In order to qualify and quantify the fractions or forms in which a metal exists in soils, it is crucial to obtain detailed knowledge and perception of the probable and genuine effects of the concentrations of these metals in the soils.

Other factors to consider include high concentrations of the metals under study, $\mathrm{pH}$, electrical conductivity, soil organic matter, translocation and transportation, and altering climatic situations. The extraction scheme developed by Tessier et al. (1979) established an extraction procedure that permits the classification of the total metal concentration into five segments: exchangeable fractions, 
carbonate-bound fractions, iron/manganese oxide-bound fractions, organic bound fractions, and residual fractions. Initially, this scheme was applied for sediments but it has now been used extensively in soil speciation. The analysis was performed to obtain the fractions using analar-grade chemicals, and metal concentrations were measured using the ICP-OES machine. The speciation results deduced that the concentrations of the different fractions vary widely at each sampling location. $\mathrm{Cd}$ is mostly abundant in the exchangeable phase in all the samples analysed in the various locations. Ni in the Iresa-apa plantation (29.9\%) and Co in Acharu plantation (29.9\%) also showed appreciable concentrations in the $\mathrm{Fe} / \mathrm{Mn}$ oxide fractions. The concentrations of $\mathrm{Pb}$ and $\mathrm{Cu}$ were highest in the organic fraction. Metals in the organic phase are more released into soil solution when compared to the residual phase fractions. Chromium and Zinc were mostly associated with the residual phase when the values of the residual phase were compared with other geochemical fractions. The plantations under study that recorded highest concentrations of $\mathrm{Cr}$ and $\mathrm{Zn}$ in the residual fractions were 87.9\% (Okitipupa), 86.3\% (Ikire), 82.7\% (Apoje), 90.3\% (Onishere), 89.7\% (Benin City), and 85.6\% (Nsukka).

The results of the sequential extraction show that mostly $\mathrm{Cr}$ and $\mathrm{Zn}$ were strongly bound to the residual/inert phase in all the soils under investigation. The potential mobility of the metals with high fractions in the residual phase is as follows: $\mathrm{Cr}(74.8 \%), \mathrm{Zn}(74.0 \%), \mathrm{Pb}(73 \%)$, $\mathrm{Fe}(69.5 \%)$, Ni $(67.0 \%), \mathrm{Cu}(63.8 \%), \mathrm{Mn}(30.5 \%)$, Co $(30.7 \%)$, and $\mathrm{Cd}(25.9 \%)$. These values were high when compared to the values of other metals in the other mobile and potentially mobile fractions. The bioavailability of the metals in soils were linked to their benefits or toxicity.

\section{Acknowledgements}

The authors acknowledge the Cape Peninsula University of Technology, South Africa for funding our research.

\section{References}

1. OBIDZINSKI K., ANDRIANI R., KOMARUDIN H., ANDRIANTO A. Enviromental and social impacts of oil palm plantations and their implications for biofuel production in Indonesia, Ecology and Society 17 (1), 131, 2012.

2. YAAP B., STRUEBIG M., PAOLI G., KOH L.P. Mitigating the biodiversity impacts of oil palm development-Reviews. In: Perspectives in Agriculture, Veterinary Science, Nutrition and Natural Resources 5 (19), 1, 2010.

3. GILBERT D. Oil palm and the palm oil industry in Ghana, A brief history, International Research Journal of Plant Science 4 (6), 158, 2013.

4. OLAGUNJU F. I.Economics of oil palm processing in southwestern Nigeria, International Journal of Agricultural Economics and Rural Development 1 (2), 69, 2008.

5. YAO Z., LI J., XIE H., YU C. Review of remediation technologies of soil contaminated by heavy metals, Proceduris Enviromental Sciences 16 (1), 722729, 2012.
6. KHAN S., CAO Q., ZHENG Y.M., HUANG Y.Z., ZHU Y.G. Health risks of heavy metals on contaminated soils and food crops irrigated with waste water in Beijing, China, Enviromental Pollution 152 (3), 686, 2008.

7. WUANA A.R., FELIX E.O. Heavy metals in contaminated soils: A review of sources, chemistry, risks, and best available strategies for remediation, ISRN - Ecology 1, 1, 2011.

8. SINGH R., GUATAM N., MISHRA A., GUPTA R. Heavy metals and living systems: An overview, Indian Journal of Pharmacology 43 (3), 246, 2011.

9. BARAKAT M.A. Review article: New trends in removing heavy metals from industrial waste water, Arabian Journal of Chemistry, 4 (4), 361, 2011.

10. TOKALIOGU S., KAFTAL S., BIROL G. Application of a three stage sequential extraction procedure for the determination of extractable metal contents in highway soils, Turkish Journal of Chemistry 27 (2003), 333, 2001.

11. TESSIER A., CAMPBELL P.G.C., BISSON M. Sequential extraction procedure for the speciation of particulate trace metals, Analytical Chemistry, 51 (7), 844,1979.

12. ZIMMERMAN A.J., WEINDORF D.C. Heavy metal and trace metal analysis in soil by sequential extraction: A review of procedures, International Journal of Analytical Chemistry, 2010 (2), 1, 2010.

13. LELEYTER L., PROBST J.L. A sequential extraction procedure for the speciation of particulate trace elements in river sediments, International Journal of Enviromental Analytical Chemistry, 73 (2), 109, 1999.

14. HE Q., REN Y., MOHAMMED I., ALI M., HASSAN W., ZENG F. Assessment of trace and heavy metal distribution by four sequential extraction procedures in a contaminated soil, Soil and Water Reserve 8 (2), 71, 2013.

15. OKORO H.K., FATOKI O.S., ADEKOLA F.A., XIMBA B.J., SNYMAN R.G. A review of sequential extraction procedures for heavy heavy metals speciation in soils and sediments, Open Access Scientific Reports 1 (1), 181, 2011.

16. CAPPUYNS V. A critical evaluation of single extractions from the SMT program to determine trace element mobility in sediments, Applied and Environmental Science. 2010 (2010), 1, 2012.

17. YU B., WAG Y., ZHOU Q. Human health risk assessment based on toxicity characteristics leaching procedure and simple bioaccessibility extraction test of toxic metals in urban street dust of Tianjin, China, PLoS ONE 9 ( 3), 2014.

18. FU X., CUI Z., ZANG G. Migration, speciation and distribution of heavy metals in an oil polluted soil affected by crude oil extraction processes, Environmental Science: Processes and Impacts 16 (1), 1737, 2014.

19. URE A.M., QUEVAUVILLER P.H., MUNTAU H., GRIEPINK B. Speciation of heavy metals in soils and sediments; An account of the improvement and harmonization of extraction techniques undertaken under the auspices of the BCR of the commission of the European communities, International Journal of Enviromental Analytical Chemistry 51 (4), 135, 1993.

20. ORISAKWE O.E., BLUM J.L., SUJAK S. AND ZELIKOFF J.T. Metal pollution in Nigeria: A biomonitoring update. Journal of Health and Pollution 4 (6), 40, 2014.

21. RODRIGUEZ L., RUIZ E., ALONSO-AZCARATE J., RINCON J. Heavy metal distribution and chemical speciation in tailings and soils around a $\mathrm{Pb}-\mathrm{Zn}$ mine in Spain, Journal of Enviromental Management, 90 (2), 1106, 2009.

22. LAKE D.L., KIRK P.W.W., LESLER J.N. Fractionation, characterization and speciation of heavy metals in sewage, sludge and sludge-amended soils: A review, Journal of Enviromental Quality 13 (2), 175, 1984. 
23. HE O.B., SINGH R. Effect of organic matter on the distribution, extractability and uptake of cadmium in soils, Journal of Soil Science 44, 641, 1993.

24. IWEGBUE C.M.A., AROMORO F.O., IWEGBUE C.E., EGUAVOEN O. Levels of $\mathrm{Cd}, \mathrm{Cu}, \mathrm{Cr}, \mathrm{Ni}, \mathrm{Zn}, \mathrm{Pb}$ and $\mathrm{Mn}$ in some species from Orogodo river, Nigeria, Journal of the Chemical Society of Nigeria 36 (1), 37, 2011.

25. NSIKAK U.B., WINIFRED U.A., IFEDOLAPO O.O. Analytical reference of trace metal speciation in environmental and biophysicochemical systems, American Journal of Analytical Chemistry, 4 (1), 633, 2013.

26. OSU I.C., OGOKO E.C.,OKORO I. A Chemical speciation and distribution of heavy metals in soil of waste dump site at various automobile mechanic workshops of south-south Nigeria, American Academic and Scholarly Research Journal, 5 (1), 1, 2013.

27. ORISAKWE O.E., BLUM J.I., SIYAK S., ZELIKOFF J.T. Metal pollution in Nigeria: A biomonitoring update. Journal of Health Pollution, 6 (1), 40, 2014.

28. BRANDSHAW D.K., THOMPSON L. The analysis of water and waste water by U. S. EPA method 200.7 using the optima 8300 ICP-OES and prepFAST Auto dilutin/ calibration system 2003.

29. ACOSTA A., MUNEVAR F. Bud rot on oil palm plantations: Link to soil physical properties and nutrient status, Better Crops International, 17 (2), 22, 2003.

30. AWETO A.O., ENARUVBE G.O. Catenary properties of soil properties under oil palm plantations in southwestern Nigeria, Ethiopian Journal of Environmental Studies and Management, 3 (1), 1, 2007.

31. MURUNGI C.K., HARUM J.B. Speciation of zinc and copper in open air automobile mechanic workshop soils in Ngara area-Nairobi Kenya. Resources and Environment, 3 (5), 145, 2013.

32. AJALA L.O., ONWUKEME V. Speciation of some trace metals in flood plain soil of Enugu, Nigeria, Journal of Applied Chemistry 1 (6), 9, 2012.

33. GAMA-CASTRO J.E., SOLLEIRO-REBOLLEDO E., VALLEJO-GOMEZ E. Weathered pumice influence on selected alluvial soil properties in west Nayarit, Mexico, Soil and Tillage Research, 55 (3-4), 143, 2000.

34. IQBAL J., THOMASSON J.A., JENKINS J.N., Owens P.R., Whisler F.D. Spatial variability analysis of soil physical properties of alluvial soils, Journal of Soil Science Society of America, 69 (4), 1338, 2005.

35. CONESA H.M., FAZ A., ARNALDOS R. Heavy metal accumulation and tolerance in plants from mine tailings of the semiarid Cartagena-La Union mining district, Science of the Total Environment, 366 (1), 1, 2006.

36. ASHRAF M.A., MAAH M.J., I. YUSOFF I. Chemical Speciation and Potential Mobility of Heavy Metals in the Soil of Former Tin Mining Catchment. The Scientific World Journal 2012 (2012), 1, 2012.

37. ANJU M., BANARJEE D.K. Associations of cadmium, zinc and lead in soils from a lead and zinc mining area as studied by single and sequential extractions, Environmental Monitoring and Assessment, 176 (1), 67, 2011.

38. RAMIREZ M., MASSOLO S., FRACHE R., CORREA J.A. "Metal speciation and environmental impact on sandy beaches due to El Salvador copper mine, Chile," Marine Pollution Bulletin, 50 (1), 62, 2005.

39. SHRIVASTAVA S..K, BANERJEE D.K. Speciation of metals in sewage sludge amended soils, Water, Air and Soil Pollution 152, 219, 2004.

40. SOBCZYNSKI T., SIEPAK J. Speciation of heavy metals in bottom sediments of lakes in the area of Wielkopolski
National Park, Polish Journal of Environmental Studies 10 (6), 463, 2001.

41. JONES L.H.P., JARVIS S.C. The fate of heavy metals, in The Chemistry of Soil Processes, Wiley, New York, NY, USA, 593, 1981.

42. LABIB F.B., KHALIL J.B,. HALAKA S.H. Heavy metals in some soils and clay beds of Bahariya Oasis, Egypt, Agrochimica, 33 (1-2), 75, 1989.

43. HAUNG J., HAUNG R., JIAO J.J., CHEN K. "Speciation and mobility of heavy metals in mud, in coastal reclamation areas in Chenzhen, China," Environment Geology, 53 (1), 221, 2007.

44. NORDBERG G.F. Chelating agents and cadmium toxicity: Problems and prospects", Enviromental Health and Perspective 54 (1), 213, 1984.

45. SEARS M.E., KER K.J.R., BRAY R.I. Arsenic, cadmium, lead and mercury in sweat: A systematic review, Journal of Enviromental and Public Health, 2012 (2012), 1, 2012.

46. NG S.K., EBNETER A., GILHOTRA J.S. Hip-implant related chorio-retinal cobalt toxicity, Indian Journal of Ophthamology, 63 (1), 35, 2013.

47. ZHANG M.K., LIU X.Y., WANG H. Use of single extraction methods to predict the bioavailability of heavy metals in polluted soils to rice, Communications in Soil Science and Plant Analysis 41 (7), 820, 2010.

48. RABINOWITZ M.B., BELLINGER D.C. Soil lead blood lead relationship among Boston children, Bulletin of Environmental Contamination and Toxicology, SpringerVerlag, New York, 1993

49. STAUDINGER K.C., ROTH V.S. Occupational lead poisoning, American Family Physician 57 (4), 719, 1998.

50. LIANG Q., ZHOU B. Copper and manganese induce yeast apoptosis via different pathways, Molecular Biology of the Cell, 8 (13), 4741, 2009.

51. OGUNSEITAN O.A., SCHOENUNG J.M., SAPHORES J.D., SHAPIRO A.A. The electronics revolution: From e-wonderland to e-wasteland, Science 326 (5953), 670, 2007.

52. SCHWARZ K. Elements newly identified as essential for animals, In: Nuclear Activation Techniques in the International Atomic Energy, $5^{\text {th }}$ ed. Vienna, 1972.

53. MOHAMMED S.S., BATU M.A., MOHAMMED M.B. Analysis of chromium in dumpsite samples using AAS and EDXRF techniques, Research Journal of Chemical Science 2 (12), 65, 2012.

54. SEIDAL J.C., CORWIN C.J. Total chromium and hexavalent chromium occurrence analysis, Water Reserve Foundation, USEPA, Denver, 2013.

55. LAWRENCE A.L., FOX J., CASTILLE JR. F.J. Decreased toxicity of copper and manganese ions to shrimp Nauplii in the presence of EDTA, Journal of the World Mariculture Society 12 (1), 271, 1981.

56. FRY R.S., ASHWELL M.S., LLOYD K.E., O'NAN A.T., FLOWERS W.L., STEWART K.R., SPEARS J.W. Amount and source of dietary copper affects small intestine morphology, duodenal lipid peroxidation, hepatic oxidative stress and MRNA expression of hepatic copper regulatory proteins in weanling pigs, Journal of Animal Science, 90 (90), 3112, 2012.

57. ZHANG P.D. Determination of copper in wastewater by beta-convection new spectrophotometry, Public Medicine, 19 (3), 471, 1999.

58. STEVENS R.G., JONES D.Y., MICOZZI M.S., TAYLOR P.R. Body iron stores and the risk of cancer, Northern England Journal of Medicine, 319 (1), 1047, 1988.

59. COMRAD M.E. Excess iron and catastrophic illness, American Journal of Hematology 43 (1), 234, 1993. 
60. CHEN J.B., SIGNY B.U., GAILLARDET J., LOUVAT B., YANG Y.N. Iron isotopes in the Seine river (France): Natural versus anthropogenic sources, Geochimica et Cosmochimica Acta, 128 (1), 128, 2014.

61. HAASE H., LOTHAR R. The immune system and the impact of zinc during aging, Immunity and Aging, 6 (9), 1, 2009.

62. FOSMIRE J. Zinc toxicity, American Journal of Clinical Nutrition, 51 (2), 225, 1990.
63. KUCHA H., MARTINS A., OTTENBURGS R. Primary minerals of $\mathrm{Zn}-\mathrm{Pb}$ mining and metallurgical dumps and their environmental behavior at Pllombiers, Belgium, European Journal of Mineralogy, 8 (1), 93, 1996.

64. POONKOTHAI B., VIJAYAVATHI B.S. Nickel as an essential element and toxicant, International Journal of Environmental Sciences, 1 (4), 285, 2012. 